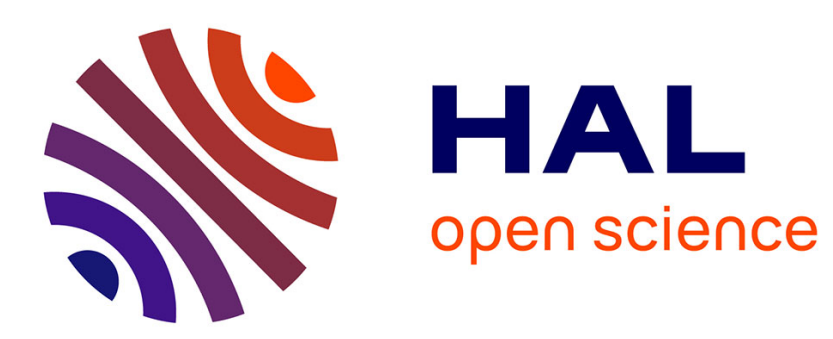

\title{
High Temperature Reaction of MCrAlY Coating Compositions with $\mathrm{CaO}$ Deposits
}

\author{
Thomas Gheno, Gerald H Meier, Brian Gleeson
}

\section{To cite this version:}

Thomas Gheno, Gerald H Meier, Brian Gleeson. High Temperature Reaction of MCrAlY Coating Compositions with CaO Deposits. Oxidation of Metals, 2015, 84 (1-2), pp.185-209. 10.1007/s11085015-9550-7 . hal-01982750

\section{HAL Id: hal-01982750 https://hal.science/hal-01982750}

Submitted on 15 Jan 2019

HAL is a multi-disciplinary open access archive for the deposit and dissemination of scientific research documents, whether they are published or not. The documents may come from teaching and research institutions in France or abroad, or from public or private research centers.
L'archive ouverte pluridisciplinaire HAL, est destinée au dépôt et à la diffusion de documents scientifiques de niveau recherche, publiés ou non, émanant des établissements d'enseignement et de recherche français ou étrangers, des laboratoires publics ou privés. 


\title{
High temperature reaction of MCrAlY coating compositions with $\mathrm{CaO}$ deposits
}

\author{
Thomas Gheno (iD), Gerald H. Meier and Brian Gleeson \\ Department of Mechanical Engineering and Materials Science, \\ University of Pittsburgh, Pittsburgh PA 15261, USA \\ Email: thg14 at pitt.edu
}

This is a post-peer-review, pre-copyedit version of an article published in

Oxidation of Metals. The final version is available online at: https://doi.org/10.1007/s11085-015-9550-7

\begin{abstract}
The reactivity of $\beta-\mathrm{NiAl}+\gamma$-Ni-based NiCoCrAlY alloys with and without $\mathrm{CaO}$ deposits was studied by means of isothermal exposures in air. Reaction with $\mathrm{CaO}$ at $1100{ }^{\circ} \mathrm{C}$ produced multi-layer scales of $\mathrm{Al}_{2} \mathrm{O}_{3}$ and calcium aluminates, and a mixture of liquid calcium chromate and nickel-cobalt oxide particles. Calcium chromate formation was a rapid, transient process, and the transition to a steady-state of slower $\mathrm{Al}_{2} \mathrm{O}_{3}$ growth was favored by increasing the alloy $\beta$ fraction. The thermally-growing $\mathrm{Al}_{2} \mathrm{O}_{3}$ reacted with the deposit to form calcium aluminates in a solid-state diffusion process, which led to an increased oxidation rate. The analysis of $\mathrm{Al}_{2} \mathrm{O}_{3}$ growth kinetics in the production-destruction regime was used to account for the increased flux of aluminum entering the multi-layer scale. The effect of temperature on the ability to kinetically sustain an $\mathrm{Al}_{2} \mathrm{O}_{3}$ scale was then evaluated on the basis of Wagner's criterion. Predicted results were consistent with the experimentally observed absence of passivation at $900{ }^{\circ} \mathrm{C}$.
\end{abstract}

Keywords MCrAlY alloys; Multi-layer scales; $\mathrm{Al}_{2} \mathrm{O}_{3}$ growth kinetics; $\mathrm{CaO}$ deposits

\section{Introduction}

Materials used in aero, marine and land-based gas turbines need to withstand significant thermo-mechanical loads, while maintaining good environmental stability. Coatings applied to structural alloys for corrosion resistance are mainly Pt-modified nickel aluminides $\beta-(\mathrm{Ni}, \mathrm{Pt}) \mathrm{Al}$, or $\mathrm{MCrAlY}(\mathrm{M}=\mathrm{Ni}$ or $\mathrm{Co}$ or both) based on $\beta$ and the $\gamma-\mathrm{Ni}$ solid solution. Reviews of the development, processing and performance of these materials can be found in Refs. [1,2]. Thermal barrier coatings (TBCs) are used on components exposed to the highest temperatures, and possess a ceramic topcoat of yttria-stabilized zirconia (YSZ) that provides thermal insulation [3-7]. In addition to the chemically aggressive combustion atmosphere, the first stage of the high-pressure turbine is subject to deposit-induced modes of degradation, due to the ingestion of impurities from the air intake and combustion process. Calciummagnesium alumino-silicates (CMAS) have been identified as a major source of concern for TBC systems [8-12]. When the topcoat surface reaches temperatures of $1150-1250{ }^{\circ} \mathrm{C}$, CMAS form glassy melts which can penetrate the openings and pores needed for strain tolerance of the TBC, and, depending on their composition, dissolve the YSZ [8-12]. Little is known about the reactivity of bondcoat materials with oxide or silicate deposits at intermediate temperatures, below their melting point. 
Deposits relevant to aero and land-based turbines have the common characteristic that their compositions vary widely depending on the fuel used and on the geographic location where the turbine is in service. Combustion of bituminous and anthracite coal, for example, tends to produce fly-ash rich in $\mathrm{SiO}_{2}$ and $\mathrm{Al}_{2} \mathrm{O}_{3}$, while fly-ash from subbituminous and lignite coals contains higher levels of $\mathrm{CaO}$ [13]. The corrosion of Ni- and Fe-base alloys by deposits rich in $\mathrm{CaO}$ and $\mathrm{CaSO}_{4}$ has been studied in the context of fluidized-bed combustion of coal. Results by Nagarajan et al. [14] indicated that corrosion with $\mathrm{CaO}-\mathrm{CaSO}_{4}$ deposits at $900{ }^{\circ} \mathrm{C}$ was associated with an oxidation-sulfidation process. Jung et al. [15] observed enhanced degradation in the presence of $\mathrm{CaO}$ during thermal cycling at $950{ }^{\circ} \mathrm{C}$ due to the formation of poorly adherent calcium aluminates, while Chiang et al. [16] reported an extremely severe type of attack due to liquid calcium chromate formation at temperatures above $1000{ }^{\circ} \mathrm{C}$. In the case of aero turbines, recent examination of the TBC degradation on an in-service airfoil $[17,18]$ showed that the YSZ topcoat had reacted with a CaO-rich CMAS, and was fully infiltrated by $\mathrm{CaSO}_{4}$.

The work reported here is part of a larger study on the reactivity of MCrAlY coatings with fly ash relevant to integrated gasification combined cycle (IGCC) systems [19-22]. A typical bondcoat composition, Ni-20Co-16Cr-23Al-0.1Y (at. \%), and a $\gamma$-rich, high $\mathrm{Cr}$ developmental composition, $\mathrm{Ni}-30 \mathrm{Co}-33 \mathrm{Cr}-12 \mathrm{Al}-0.1 \mathrm{Y}$, were selected for testing with the following individual oxides at $1100{ }^{\circ} \mathrm{C}$ : $\mathrm{CaO}, \mathrm{MgO}$, $\mathrm{Al}_{2} \mathrm{O}_{3}, \mathrm{SiO}_{2}, \mathrm{Fe}_{2} \mathrm{O}_{3}$. Only the relatively basic $\mathrm{CaO}$ and $\mathrm{MgO}$ had a significant impact, as their reaction with the thermally-grown $\mathrm{Al}_{2} \mathrm{O}_{3}$ produced calcium and magnesium aluminates, respectively. This paper addresses the case of reaction with $\mathrm{CaO}$. The reaction mechanism and the effects of alloy composition on the extent of degradation are first discussed. Emphasis is then placed on the kinetics of the solid-state reaction between $\mathrm{Al}_{2} \mathrm{O}_{3}$ and $\mathrm{CaO}$, and on the consequences this reaction has on the consumption of aluminum.

\section{Materials and experimental methods}

Ingots of nominal compositions (at. \%) Ni-20Co- $16 \mathrm{Cr}-23 \mathrm{Al}-0.1 \mathrm{Y}$ and $\mathrm{Ni}-30 \mathrm{Co}-$ $33 \mathrm{Cr}-12 \mathrm{Al}-0.1 \mathrm{Y}$ were made by argon-arc melting, followed by drop casting into 10 $\mathrm{mm}$ diameter rods which were then homogenized in vacuum for $6 \mathrm{~h}$ at $1200{ }^{\circ} \mathrm{C}$ plus another $48 \mathrm{~h}$ at $1150{ }^{\circ} \mathrm{C}$. All processing was conducted at the Materials Preparation Center of the Ames Laboratory [23]. Specimens approximately $1 \mathrm{~mm}$ thick were cut from the heat-treated rods, ground using SiC paper to a P1200-grit finish, then degreased with detergent and ultrasonically cleaned in ethanol before exposure.

Micrographs of the alloys after $50 \mathrm{~h}$ annealing in dry air at $1100{ }^{\circ} \mathrm{C}$ and air cooling are shown in Fig. 1. Both alloys exhibit a primarily $\beta-\gamma$ microstructure at this temperature. In addition, the $\gamma$-rich $\mathrm{Ni}-30 \mathrm{Co}-33 \mathrm{Cr}-12 \mathrm{Al}-0.1 \mathrm{Y}$ formed 1 vol. $\% \sigma$, while the $\beta$-rich $\mathrm{Ni}-20 \mathrm{Co}-16 \mathrm{Cr}-23 \mathrm{Al}-0.1 \mathrm{Y}$ contained a small amount $(\sim 0.1$ vol. $\%)$ of yttrium-rich intermetallics. An even smaller amount of yttrides were present in the $\gamma$-rich alloy, reflecting the higher solubility of $\mathrm{Y}$ in $\gamma$. Phase compositions measured by SEM-EDS and phase fractions obtained by image analysis using the ImageJ software [24] are given in Table 1. Overall compositions calculated from these experimental results are within 0.5 at. \% of the nominal compositions.

Isothermal corrosion experiments were conducted at 900 and $1100{ }^{\circ} \mathrm{C}$ in flow- 
Table 1: Bulk phase compositions (SEM-EDS) and phase fractions (image analysis) of alloys $\mathrm{Ni}-20 \mathrm{Co}-16 \mathrm{Cr}-23 \mathrm{Al}-0.1 \mathrm{Y}$ and $\mathrm{Ni}-30 \mathrm{Co}-33 \mathrm{Cr}-12 \mathrm{Al}-0.1 \mathrm{Y}$ measured after $50 \mathrm{~h}$ heat treatment in dry air at $1100{ }^{\circ} \mathrm{C}$. Ni-20Co- $16 \mathrm{Cr}-23 \mathrm{Al}-0.1 \mathrm{Y}$ also contains 0.1 vol. $\%$ yttrides.

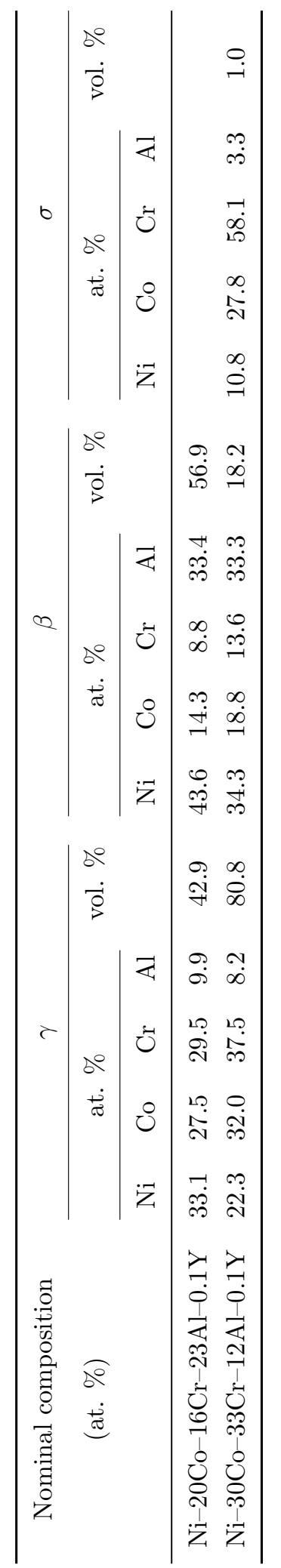



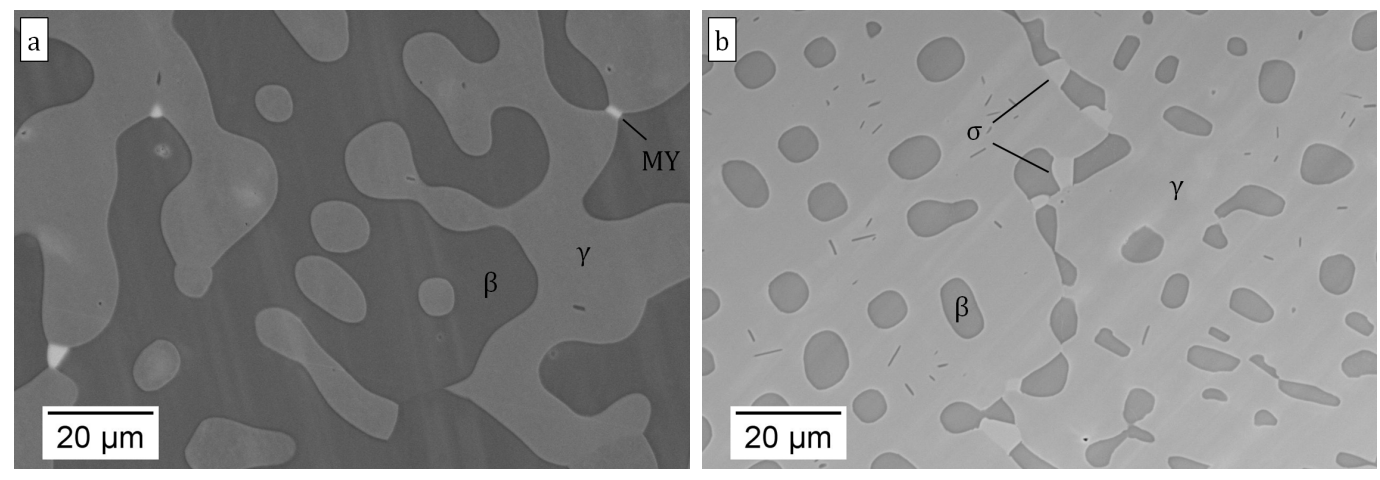

Figure 1: Micrographs of (a) Ni-20Co-16Cr-23Al-0.1Y and (b) Ni-30Co-33Cr-12Al-0.1Y after $50 \mathrm{~h}$ heat treatment in dry air at $1100{ }^{\circ} \mathrm{C}$.

ing dry air, using an horizontal tube furnace. Linear gas flow rates were set to about $1 \mathrm{~mm} \mathrm{~s}^{-1}$ at reaction temperature, with a total pressure slightly over $1 \mathrm{~atm}$. Deposits were prepared by mixing laboratory grade reagents in ethanol, and then applying the resulting slurry to one face of a given specimen using a dropper. The procedure was adjusted to produce approximately uniform $35 \pm 5 \mathrm{mg} \mathrm{cm}^{-2}$ deposits after evaporation of the ethanol. In addition to time-lapse experiments, reaction kinetics were studied by thermogravimetric analysis (TGA) using a Setaram TAG thermobalance. A relatively high heating rate, $99 \mathrm{~K} / \mathrm{min}$, was chosen to reduce time spent at intermediate temperatures and hence resemble the time-lapse experiments in which the furnace was heated prior to inserting the specimens. For TGA experiments, a hole was drilled in the $\mathrm{Ni}-20 \mathrm{Co}-16 \mathrm{Cr}-23 \mathrm{Al}-0.1 \mathrm{Y}$ specimen, which was then dipped into the $\mathrm{CaO}$ slurry, and suspended in the thermobalance using $\mathrm{Pt}$ wire - both specimen faces were coated. As will be shown later, reaction of $\mathrm{Ni}-$ $30 \mathrm{Co}-33 \mathrm{Cr}-12 \mathrm{Al}-0.1 \mathrm{Y}$ with $\mathrm{CaO}$ produced significant amounts of liquid. For this reason $\mathrm{CaO}$ was applied on one face only, and the specimen laid flat on an $\mathrm{Al}_{2} \mathrm{O}_{3}$ crucible, also suspended in the thermobalance using Pt wire. In this case the weight gain corresponding to the oxidation of the uncoated regions was subtracted from the TGA signal, on the basis of data obtained for the same alloy with no deposit. A blank test was conducted using a sample of dense $\mathrm{Al}_{2} \mathrm{O}_{3}$ coated with $\mathrm{CaO}$, which confirmed that $\mathrm{CaO}$ did not evaporate significantly.

Mounted cross-sections were prepared using conventional metallographic techniques, and observed by SEM with a JEOL JSM 6510 instrument, equipped with an Oxford X-Max SDD EDS detector and INCA analysis software. Oxides were examined by photo-stimulated luminescence spectroscopy (PSLS), which allows $\gamma$, $\theta$ and $\alpha$ polymorphs of $\mathrm{Al}_{2} \mathrm{O}_{3}$ to be distinguished [25], using a $633 \mathrm{~nm} \mathrm{HeNe}$ laser in a Renishaw inVia Raman microscope.

\section{Results}

The Ni-20Co-16Cr-23Al- $-1 \mathrm{Y}$ and $\mathrm{Ni}-30 \mathrm{Co}-33 \mathrm{Cr}-12 \mathrm{Al}-0.1 \mathrm{Y}$ alloys were reacted in dry air at $1100{ }^{\circ} \mathrm{C}$, with and without $\mathrm{CaO}$ deposits, for durations ranging between 5 and $250 \mathrm{~h}$. In the absence of a deposit, both alloys formed adherent $\mathrm{Al}_{2} \mathrm{O}_{3}$ scales, with no or very little oxides of Ni, Co or Cr. Scales obtained after $250 \mathrm{~h}$ oxidation, 

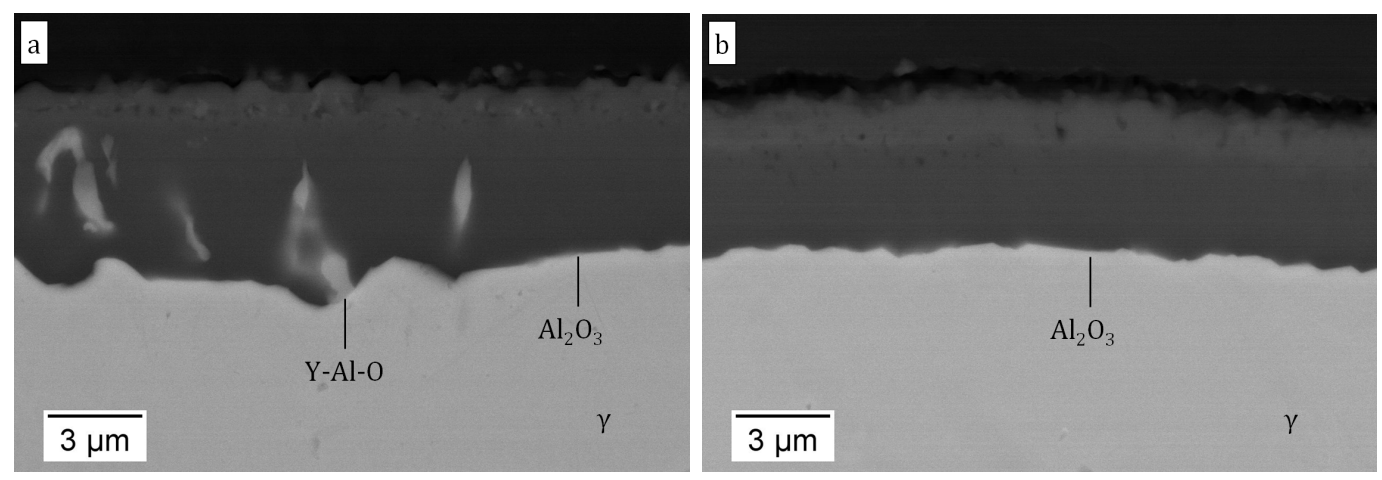

Figure 2: Alumina scales formed after $250 \mathrm{~h}$ oxidation of (a) $\mathrm{Ni}-20 \mathrm{Co}-16 \mathrm{Cr}-23 \mathrm{Al}-0.1 \mathrm{Y}$ and (b) Ni-30Co-33Cr-12Al-0.1Y in dry air at $1100{ }^{\circ} \mathrm{C}$.
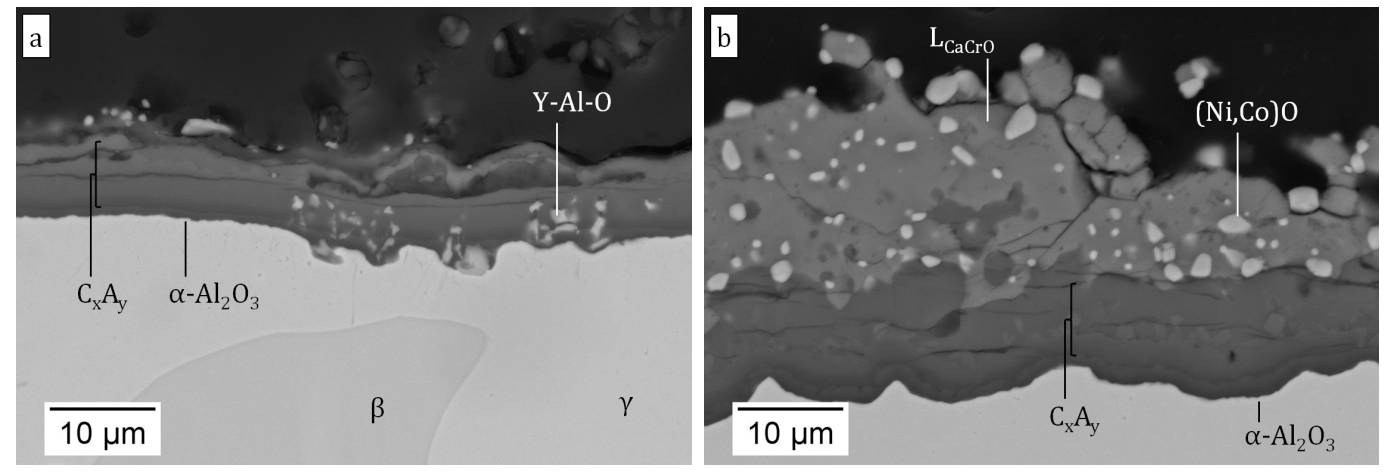

Figure 3: Reaction morphology observed after 50 h exposure of (a) Ni-20Co-16Cr-23Al$0.1 \mathrm{Y}$ and (b) $\mathrm{Ni}-30 \mathrm{Co}-33 \mathrm{Cr}-12 \mathrm{Al}-0.1 \mathrm{Y}$ in dry air with $\mathrm{CaO}$ at $1100{ }^{\circ} \mathrm{C}$.

shown in Fig. 2, were thick enough for reliable chemical analysis by SEM-EDS. The outer part was thus found to contain $0.5-1$ at. \% $\mathrm{Cr}$ in $\mathrm{Al}_{2} \mathrm{O}_{3}$.

In the presence of $\mathrm{CaO}$ deposits, the resulting scales comprised several layers of calcium aluminates $\left(x \mathrm{CaO}-y \mathrm{Al}_{2} \mathrm{O}_{3}\right.$, denoted $\left.\mathrm{C}_{x} \mathrm{~A}_{y}\right)$. Micrographs obtained after $50 \mathrm{~h}$ reaction, shown in Fig. 3, are representative of the reaction morphologies developed for all exposure durations. The layer sequence was Al-rich $\mathrm{CA}_{2}$ nearest to the substrate, followed by equimolar $\mathrm{CA}$, and occasionally the Ca-rich $\mathrm{C}_{12} \mathrm{~A}_{7}$ and $\mathrm{C}_{3} \mathrm{~A}$ toward the $\mathrm{CaO}$ deposit. These were identified by matching compositions measured by SEM-EDS to the intermediate compounds known to exist in the $\mathrm{CaO}-\mathrm{Al}_{2} \mathrm{O}_{3}$ system (see Fig. 4a). A thin and continuous Al-rich oxide layer, identified as $\alpha-\mathrm{Al}_{2} \mathrm{O}_{3}$ by PSLS, was always present between the metal and the first aluminate layer. In addition, the $\gamma$-rich alloy produced a thick outer layer of calcium chromate, with $(\mathrm{Ni}, \mathrm{Co}) \mathrm{O}$ particles embedded throughout (Fig. 3b). These were occasionally found in small amounts on the $\beta$-rich alloy. It is noted that spallation of the reaction products occurred on a significant fraction of the surfaces of both alloys.

Calcium oxide is known [16] to react with the chromium contained in MCrAlY alloys to form a low-melting calcium chromate, denoted here as $\mathrm{L}_{\mathrm{CaCrO}}$, which is liquid at $1100{ }^{\circ} \mathrm{C}\left(T_{\text {eutectic }}=1061{ }^{\circ} \mathrm{C}\right.$, see Fig. $\left.4 \mathrm{~b}\right)$. The thickness of this layer was not uniform, which made measurements difficult. Qualitatively, the calcium chromate was found to develop rapidly on the $\gamma$-rich $\mathrm{Ni}-30 \mathrm{Co}-33 \mathrm{Cr}-12 \mathrm{Al}-0.1 \mathrm{Y}$ within 5 

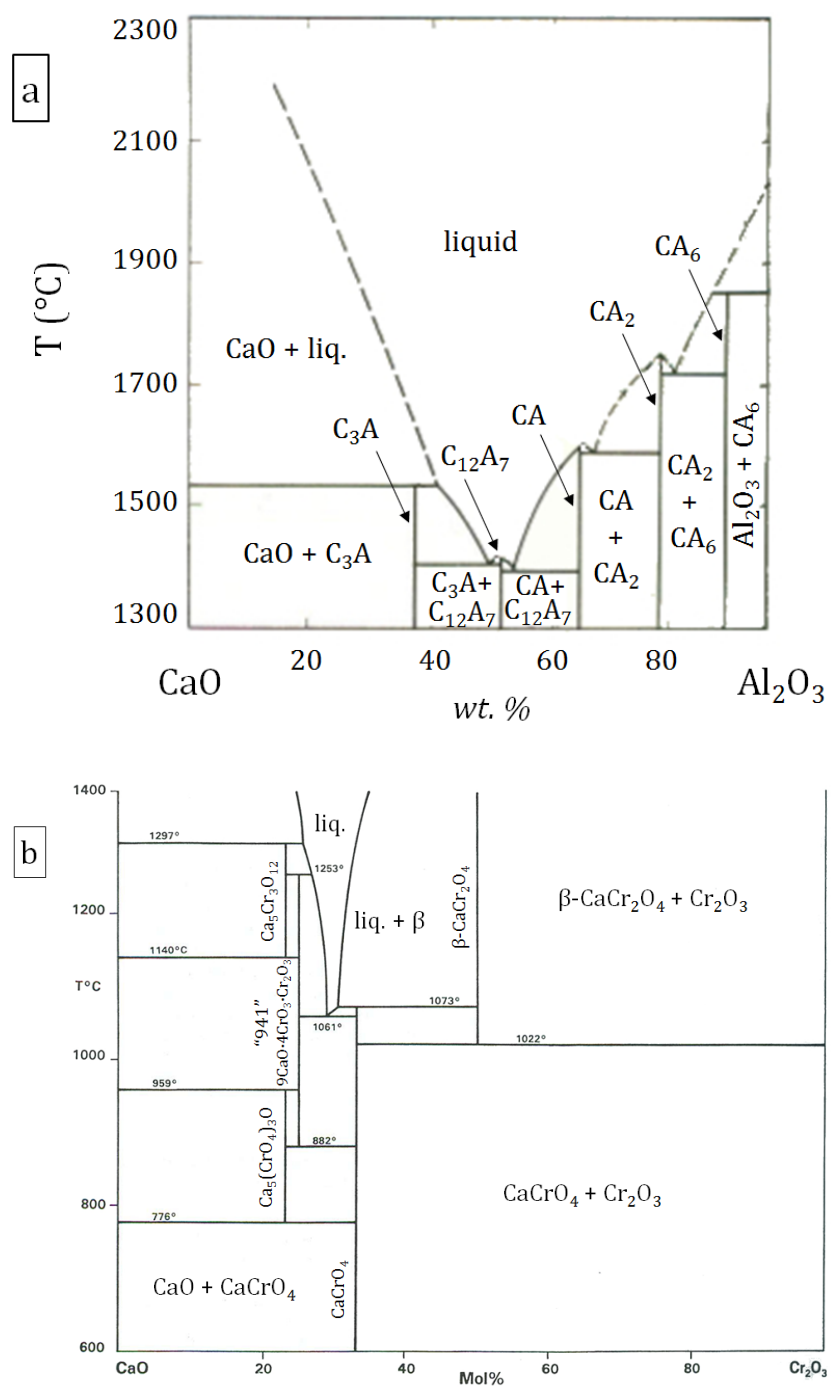

Figure 4: Pseudo-binary phase diagrams. (a) $\mathrm{CaO}-\mathrm{Al}_{2} \mathrm{O}_{3}$ system, adapted from Ref. [26]; (b) $\mathrm{CaO}-\mathrm{Cr}_{2} \mathrm{O}_{3}$ system, adapted from Ref. [27].

$\mathrm{h}$ exposure, and to not significantly thicken thereafter. The (Ni,Co)O particles did, however, grow to an appreciable extent, from an average diameter of $0.6 \pm 0.2 \mu \mathrm{m}$ after $5 \mathrm{~h}$ to $2.1 \pm 0.7 \mu \mathrm{m}$ after $250 \mathrm{~h}$. The thickness of the $\beta$ dissolution, $\mathrm{C}_{x} \mathrm{~A}_{y}$ and $\mathrm{Al}_{2} \mathrm{O}_{3}$ regions are plotted against the square-root of time, $t^{1 / 2}$, in Fig. 5 , and compared with the relevant values obtained without deposit. All variables are seen to follow approximately parabolic kinetics, as expected for diffusion-controlled processes. The extent of $\beta$ dissolution is much greater in $\mathrm{Ni}-30 \mathrm{Co}-33 \mathrm{Cr}-12 \mathrm{Al}-0.1 \mathrm{Y}$ than in $\mathrm{Ni}-20 \mathrm{Co}-16 \mathrm{Cr}-23 \mathrm{Al}-0.1 \mathrm{Y}$, due to the lower starting $\beta$ fraction in the former, 18 versus 57 vol. \%. Alumina and $\mathrm{C}_{x} \mathrm{~A}_{y}$ thicknesses, however, are comparable. For both alloys, reaction with $\mathrm{CaO}$ yielded a thinner $\mathrm{Al}_{2} \mathrm{O}_{3}$ layer but deeper $\beta$ dissolution, i.e. more extensive $\mathrm{Al}$ consumption, than reaction with no deposit. This will be discussed in more detail later in this paper.

The observations discussed above suggest that calcium chromate formed only during an initial transient stage. In order to test this hypothesis, Ni-20Co- $16 \mathrm{Cr}-$ 

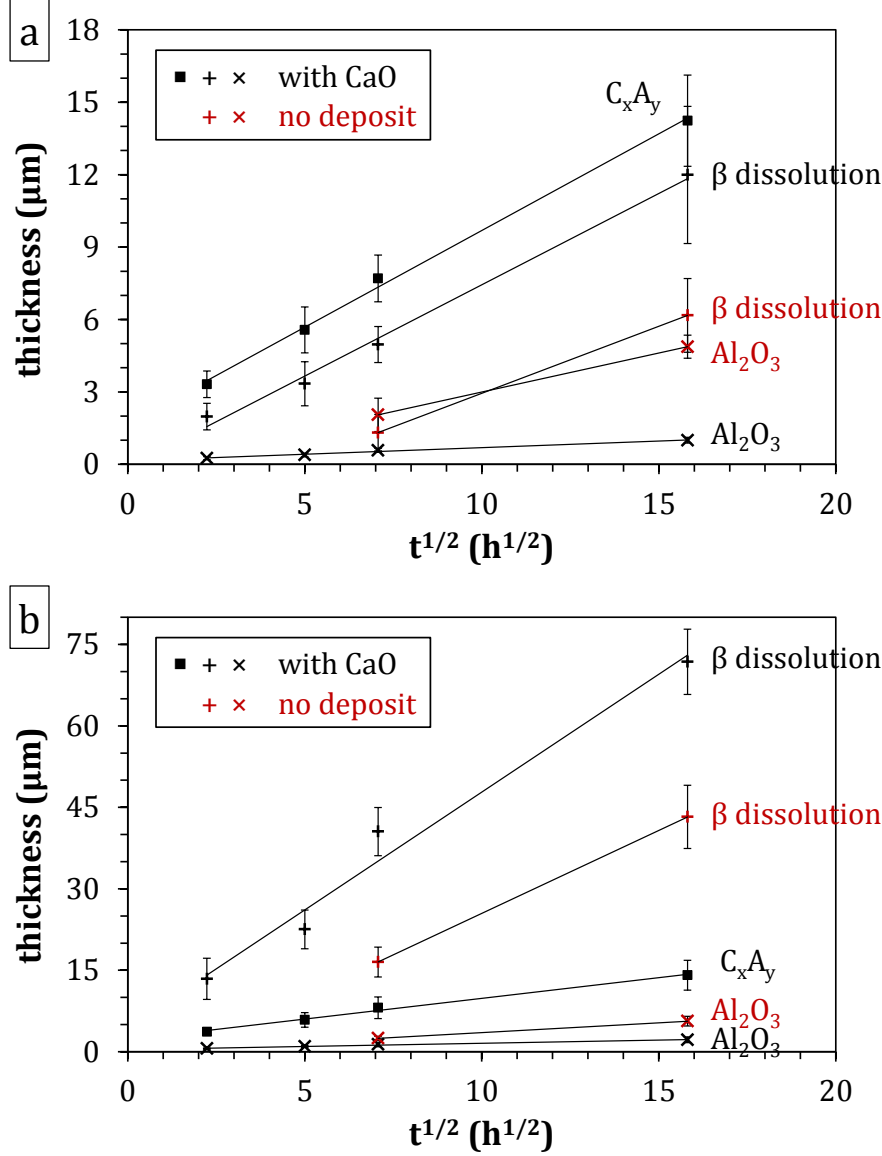

Figure 5: Thickness of reaction layers measured after exposure of (a) Ni-20Co-16Cr-23Al$0.1 \mathrm{Y}$ and $(\mathrm{b}) \mathrm{Ni}-30 \mathrm{Co}-33 \mathrm{Cr}-12 \mathrm{Al}-0.1 \mathrm{Y}$ in dry air with and without $\mathrm{CaO}$ at $1100{ }^{\circ} \mathrm{C}$.

$23 \mathrm{Al}-0.1 \mathrm{Y}$ and $\mathrm{Ni}-30 \mathrm{Co}-33 \mathrm{Cr}-12 \mathrm{Al}-0.1 \mathrm{Y}$ were oxidized with no deposit in dry air for $10 \mathrm{~h}$ at $1100{ }^{\circ} \mathrm{C}$, growing a continuous $\mathrm{Al}_{2} \mathrm{O}_{3}$ scale. Upon subsequent exposure to $\mathrm{CaO}$ for $40 \mathrm{~h}$ in the same conditions, the $\mathrm{Al}_{2} \mathrm{O}_{3}$ reacted to yield calcium aluminates, but no calcium chromate was formed, confirming the transient nature of the latter.

The weight gains recorded by TGA at $1100{ }^{\circ} \mathrm{C}$, Fig. 6a, reflect the successive stages of the reaction process. Plots of $m=f\left(t^{1 / 2}\right)$ yielded straight lines after a sufficient time was reached (not shown here). This indicates that steady-state kinetics were parabolic for both alloys, with and without $\mathrm{CaO}$ deposits. Reaction kinetics were further studied on the basis of the local fitting procedure described in Ref. [28]. The instantaneous parabolic constant $k_{\mathrm{p}}$ was calculated in a translating time-mass window according to

$$
t=a+b m+c m^{2},
$$

where $m$ is the weight gain per unit area, and $a, b$ and $c$ are constants, with $c=\frac{1}{2 k_{\mathrm{p}}}$. This procedure allows the reaction stages to be distinguished based on the time evolution of $k_{\mathrm{p}}$, Fig. $6 \mathrm{~b}$. In the absence of $\mathrm{CaO}, \mathrm{Ni}-20 \mathrm{Co}-16 \mathrm{Cr}-23 \mathrm{Al}-$ $0.1 \mathrm{Y}$ and $\mathrm{Ni}-30 \mathrm{Co}-33 \mathrm{Cr}-12 \mathrm{Al}-0.1 \mathrm{Y}$ exhibited similar oxidation kinetics: a short $(\sim 2 \mathrm{~h})$ transient stage, associated with oxides of the base metal constituents and 

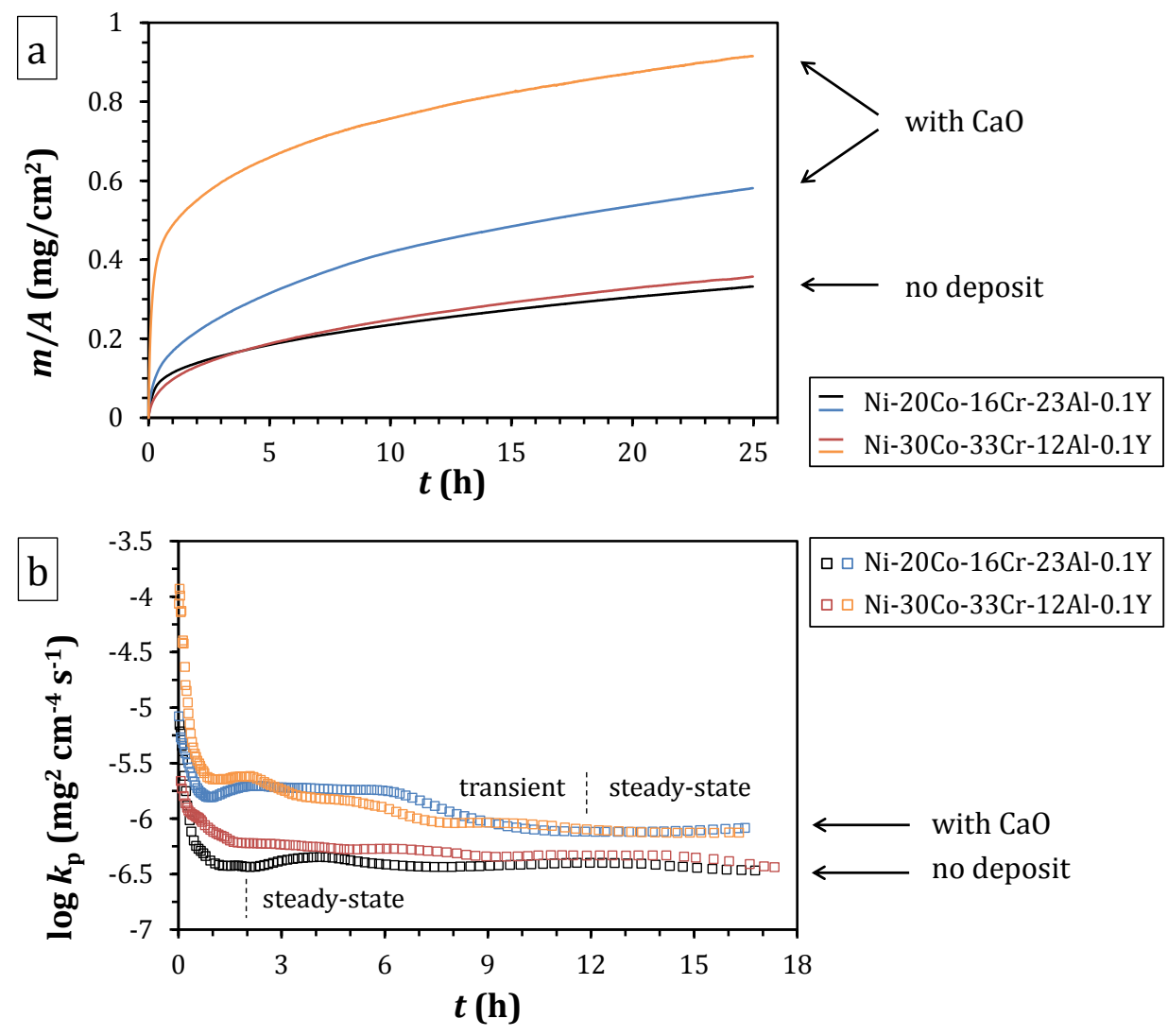

Figure 6: Reaction kinetics of $\mathrm{Ni}-20 \mathrm{Co}-16 \mathrm{Cr}-23 \mathrm{Al}-0.1 \mathrm{Y}$ and $\mathrm{Ni}-30 \mathrm{Co}-33 \mathrm{Cr}-12 \mathrm{Al}-0.1 \mathrm{Y}$ in dry air at $1100{ }^{\circ} \mathrm{C}$, with and without CaO. (a) Weight gains recorded by TGA. (b) Local parabolic constants, determined after method in Ref. [28].

metastable alumina polymorphs, was followed by a steady-state corresponding to $\alpha-\mathrm{Al}_{2} \mathrm{O}_{3}$ growth. Parabolic constants calculated by fitting Eq. (1) to TGA data over a $2-25 \mathrm{~h}$ window were found to be $3.7 \times 10^{-7}$ and $4.5 \times 10^{-7} \mathrm{mg}^{2} \mathrm{~cm}^{-4} \mathrm{~s}^{-1}$ for $\mathrm{Ni}-20 \mathrm{Co}-16 \mathrm{Cr}-23 \mathrm{Al}-0.1 \mathrm{Y}$ and $\mathrm{Ni}-30 \mathrm{Co}-33 \mathrm{Cr}-12 \mathrm{Al}-0.1 \mathrm{Y}$, respectively, in good agreement with previously reported values for the growth of $\alpha-\mathrm{Al}_{2} \mathrm{O}_{3}$ at this temperature [29-31]. In the presence of a $\mathrm{CaO}$ deposit, the rates of both transient and steady-state stages increased, and the transition was delayed. The effect of $\mathrm{CaO}$ was particularly marked in the case of $\mathrm{Ni}-30 \mathrm{Co}-33 \mathrm{Cr}-12 \mathrm{Al}-0.1 \mathrm{Y}$, which exhibited a relatively large weight gain in the beginning of the reaction. Since a thick $\mathrm{L}_{\mathrm{CaCrO}}$ $+(\mathrm{Ni}, \mathrm{Co}) \mathrm{O}$ layer formed on this alloy within $5 \mathrm{~h}$ exposure, and only small amounts were found on $\mathrm{Ni}-20 \mathrm{Co}-16 \mathrm{Cr}-3 \mathrm{Al}-0.1 \mathrm{Y}$, the elevated reaction rate is attributed to $\mathrm{L}_{\mathrm{CaCrO}}$ and $(\mathrm{Ni}, \mathrm{Co}) \mathrm{O}$ formation. As Fig. $6 \mathrm{~b}$ indicates, this accelerated process was particularly short-lived $(<1 \mathrm{~h})$. Until about $9 \mathrm{~h}$ exposure, both alloys maintained a relatively high reaction rate. The rate-limiting process associated with this period is not readily ascertained, as a continuous $\alpha-\mathrm{Al}_{2} \mathrm{O}_{3}$ layer was identified by PSLS at the base of the scale for both alloys after $5 \mathrm{~h}$ reaction. Nevertheless, both alloys did passivate, and the $k_{\mathrm{p}}$ 's eventually reached lower, approximately stable values.

An additional experiment was conducted with a $\mathrm{Ni}-33 \mathrm{Co}-35 \mathrm{Cr}-7 \mathrm{Al}-0.1 \mathrm{Y}$ alloy, which is single-phase $\gamma$ at $1100{ }^{\circ} \mathrm{C}$, and has a composition similar to that of the $\gamma$ 

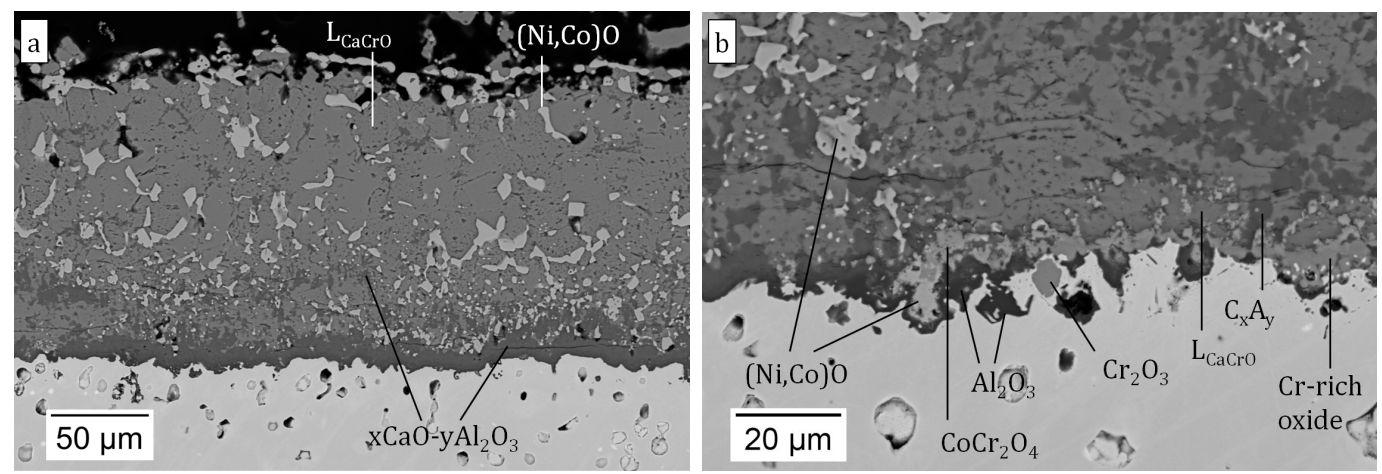

Figure 7: Reaction morphology observed after $50 \mathrm{~h}$ exposure of $100 \% \gamma$ alloy $\mathrm{Ni}^{-}-33 \mathrm{Co}-$ $35 \mathrm{Cr}-7 \mathrm{Al}-0.1 \mathrm{Y}$ in dry air with $\mathrm{CaO}$ at $1100{ }^{\circ} \mathrm{C}$. (a) overview; (b) metal/oxide interface in a zone where no continuous $\mathrm{Al}_{2} \mathrm{O}_{3}$ layer is present at the base of the scale.

in $\mathrm{Ni}-30 \mathrm{Co}-33 \mathrm{Cr}-12 \mathrm{Al}-0.1 \mathrm{Y}$ at this temperature (see Table 1 ). After $50 \mathrm{~h}$ exposure to $\mathrm{CaO}$, the $100 \% \gamma$ alloy developed a reaction morphology similar to that on $\mathrm{Ni}-$ $30 \mathrm{Co}-33 \mathrm{Cr}-12 \mathrm{Al}-0.1 \mathrm{Y}$. However, the amount of $\mathrm{L}_{\mathrm{CaCrO}}$ and $(\mathrm{Ni}, \mathrm{Co}) \mathrm{O}$ formed before passivation was much greater, and the $\sim 150 \mu \mathrm{m}$ thick calcium chromate had also embedded $\mathrm{C}_{x} \mathrm{~A}_{y}$ particles (Fig. 7a). Furthermore, local regions were found on which passivation had not yet occurred, as no layer of $\mathrm{C}_{x} \mathrm{~A}_{y}$ or $\mathrm{Al}_{2} \mathrm{O}_{3}$ was present (Fig. $7 \mathrm{~b}$ ). In these regions, calcium chromate or aluminate was not directly in contact with the metal, but instead the reaction front consisted of oxides: (Ni,Co) $\mathrm{O}, \mathrm{Al}_{2} \mathrm{O}_{3}, \mathrm{Cr}_{2} \mathrm{O}_{3}$, $\mathrm{CoCr}_{2} \mathrm{O}_{4}$, or Cr-rich oxide containing varying amounts of $\mathrm{Ca}, \mathrm{Cr}$ or $\mathrm{Co}$, with the $\mathrm{Al}_{2} \mathrm{O}_{3}$ and $\mathrm{Cr}_{2} \mathrm{O}_{3}$ sometimes present as large internal particles. These reaction products were identified based on chemical analysis by SEM-EDS.

Another $\gamma$-rich alloy, $\mathrm{Ni}-30 \mathrm{Co}-27 \mathrm{Cr}-12 \mathrm{Al}-0.1 \mathrm{Y}$, was used in a series of experiments with $\mathrm{Al}_{2} \mathrm{O}_{3}-40$ wt. $\% \mathrm{CaO}$ deposits at 900 and $1100{ }^{\circ} \mathrm{C}$. At $1100{ }^{\circ} \mathrm{C}$, the alloy formed an $\mathrm{Al}_{2} \mathrm{O}_{3}$ and $\mathrm{C}_{x} \mathrm{~A}_{y}$ layers, but no calcium chromate. This is attributed to the alloy $\mathrm{Cr}$ content, lower than that of the $\gamma$-rich alloys studied previously, and to the presence of $\mathrm{Al}_{2} \mathrm{O}_{3}$ in the deposit itself. The latter partially neutralized $\mathrm{CaO}$ by forming calcium aluminates in the deposit, which was detected by SEM-EDS after exposure. At $900{ }^{\circ} \mathrm{C}$, a mixed calcium aluminate-chromate and a continuous $\mathrm{Al}_{2} \mathrm{O}_{3}$ sublayer formed on a small fraction of the alloy surface. Passivation was only local, however, and most regions were subject to internal oxidation and nitridation, as shown in Fig. 8. Close examination of the reaction morphology indicates the presence of $\mathrm{Al}_{2} \mathrm{O}_{3}$ in the form of both internal oxide particles and a discontinuous layer located below a Cr-rich, mixed-oxide scale. This sequence suggests that the alloy initially formed an external $\mathrm{Al}_{2} \mathrm{O}_{3}$ scale, but subsequently failed to sustain its growth, on most of its surface. Figure 8 also shows that an outer calcium chromate layer had formed, with mixed $(\mathrm{Co}, \mathrm{Ni}) \mathrm{O}$ particles embedded. Exposure to a $\mathrm{CO}_{2}-$ $20 \mathrm{H}_{2} \mathrm{O}-1.6 \mathrm{O}_{2}$ gas mixture with the $\mathrm{Al}_{2} \mathrm{O}_{3}-40$ wt. $\% \mathrm{CaO}$ deposit at $900{ }^{\circ} \mathrm{C}$ yielded a similar reaction morphology to that observed in air but with no nitrides, indicating that nitridation in air was not a cause of $\mathrm{Al}_{2} \mathrm{O}_{3}$ failure, but rather a consequence.

In the absence of a deposit, oxidation of this alloy at $1100{ }^{\circ} \mathrm{C}$ led to external $\mathrm{Al}_{2} \mathrm{O}_{3}$ scaling with very little transient oxides, while at $900{ }^{\circ} \mathrm{C}$, the $\mathrm{Al}_{2} \mathrm{O}_{3}$ scale was surmounted by a layer of mixed $\mathrm{Cr}-\mathrm{Co}-\mathrm{Ni}$ oxide, and shallow $(\sim 1 \mu \mathrm{m}$ deep) 


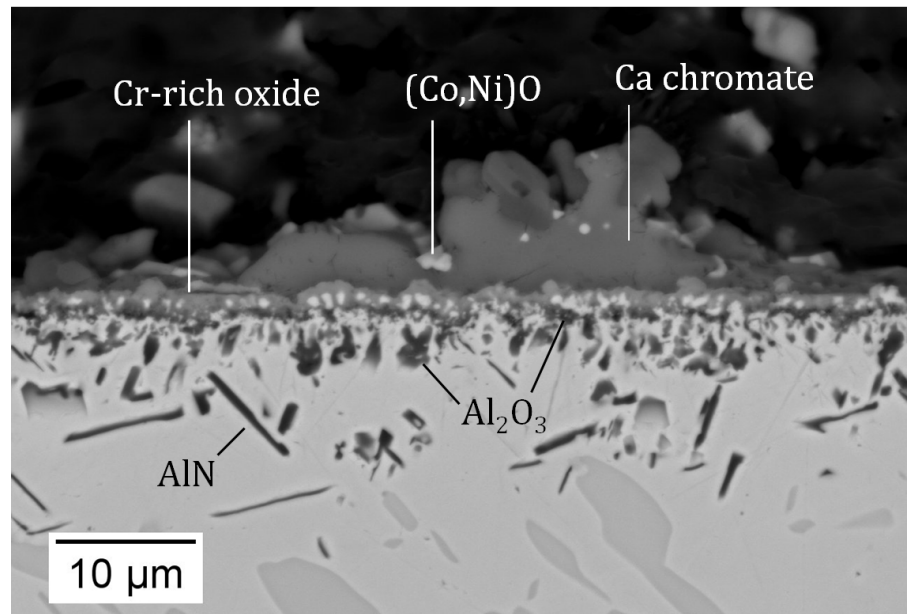

Figure 8: Reaction morphology observed after $50 \mathrm{~h}$ exposure of the $\gamma$-rich $\mathrm{Ni}-30 \mathrm{Co}-27 \mathrm{Cr}-$ $12 \mathrm{Al}-0.1 \mathrm{Y}$ (at. \%) to $\mathrm{Al}_{2} \mathrm{O}_{3}-40$ wt. $\% \mathrm{CaO}$ in dry air at $900{ }^{\circ} \mathrm{C}$.

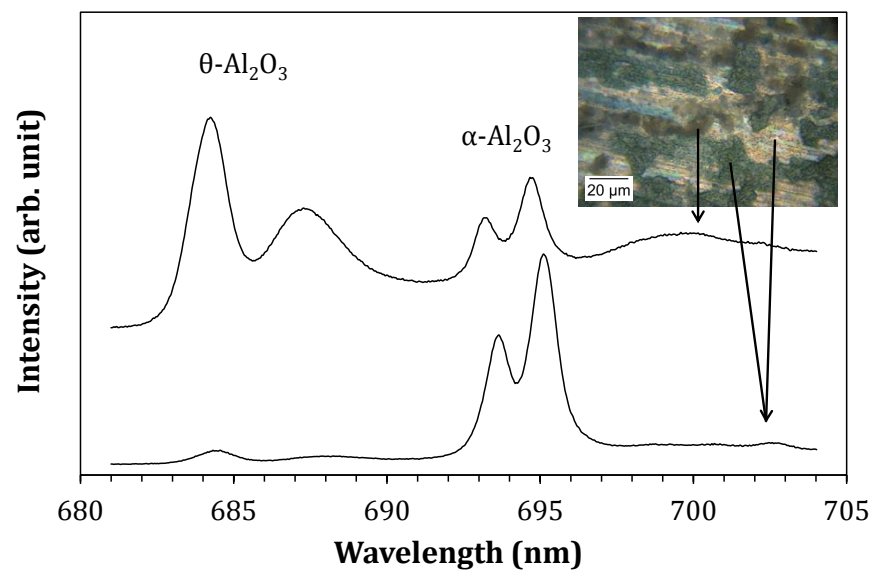

Figure 9: PSLS spectra recorded after $50 \mathrm{~h}$ exposure of the $\gamma$-rich $\mathrm{Ni}-30 \mathrm{Co}-27 \mathrm{Cr}-12 \mathrm{Al}-$ $0.1 \mathrm{Y}$ in dry air at $900{ }^{\circ} \mathrm{C}$, with no deposit, showing regions of $\alpha$ and $\theta-\mathrm{Al}_{2} \mathrm{O}_{3}$. Since $\theta-\mathrm{Al}_{2} \mathrm{O}_{3}$ luminescence is 10-12 times weaker than that of $\alpha-\mathrm{Al}_{2} \mathrm{O}_{3}$ [25], the top spectrum denotes regions primarily consisting of $\theta-\mathrm{Al}_{2} \mathrm{O}_{3}$.

$\mathrm{Al}_{2} \mathrm{O}_{3}$ intrusions were locally seen to grow into the alloy. Furthermore, the $\theta \rightarrow \alpha$ transformation was not complete after $50 \mathrm{~h}$ at $900^{\circ} \mathrm{C}$. Surface PSLS characterization showed that while most of the surface consisted of $\alpha-\mathrm{Al}_{2} \mathrm{O}_{3}$, a significant fraction was still predominantly $\theta$ (Fig. 9).

\section{Discussion}

\subsection{Influence of alloy composition}

The case of pure $\mathrm{CaO}$ deposits at $1100{ }^{\circ} \mathrm{C}$ is considered first. As noted in the introduction, Chiang et al. [16] studied the reaction of nominally $\mathrm{Al}_{2} \mathrm{O}_{3}$-forming $\mathrm{NiCrAl}$ and $\mathrm{CoCrAl}$ alloys with $\mathrm{CaO}$, and found that the formation of liquid calcium chromate led to very rapid alloy destruction. In the present study, the extent of metal 
loss due to $\mathrm{L}_{\mathrm{CaCrO}}$ and $(\mathrm{Ni}, \mathrm{Co}) \mathrm{O}$ was seen to vary quite significantly with alloy composition and, in turn, alloy microstructure. The $\beta$-rich $\mathrm{Ni}-20 \mathrm{Co}-16 \mathrm{Cr}-23 \mathrm{Al}$ $0.1 \mathrm{Y}$ rapidly established continuous $\mathrm{Al}_{2} \mathrm{O}_{3}$ and $\mathrm{C}_{x} \mathrm{~A}_{y}$ layers, which prevented the oxidation of $\mathrm{Cr}$, Ni or $\mathrm{Co}$; whereas, the $100 \% \gamma \mathrm{Ni}-33 \mathrm{Co}-35 \mathrm{Cr}-7 \mathrm{Al}-0.1 \mathrm{Y}$ sustained extensive degradation before it could passivate, and the $\gamma$-rich $\mathrm{Ni}-30 \mathrm{Co}-33 \mathrm{Cr}-12 \mathrm{Al}-$ $0.1 Y$ had an intermediate behavior.

Aluminum and chromium strongly partition to the $\beta$ and $\gamma$ phases, respectively, as seen in Table 1. Thus $\gamma$ will favor $\mathrm{L}_{\mathrm{CaCrO}}$ formation, while $\beta$ will tend to form $\mathrm{Al}_{2} \mathrm{O}_{3}$ and $\mathrm{C}_{x} \mathrm{~A}_{y}$. As suggested by Chiang et al. [16], calcium chromate is formed by reaction of $\mathrm{CaO}$ with transient chromium oxide. A remarkable finding is that, as mentioned in Section 3, the extent of transient $\mathrm{Cr}$ oxidation on the alloys studied here in the absence of a $\mathrm{CaO}$ deposit was very small. Thus, the reaction of $\mathrm{CaO}$ with chromium must be particularly rapid, which is confirmed by the TGA measurements for $\mathrm{Ni}-30 \mathrm{Co}-33 \mathrm{Cr}-12 \mathrm{Al}-0.1 \mathrm{Y}$ (Fig. 6). The fact that the (Ni,Co)O particles embedded in the chromate grew significantly with reaction time indicates that they did not precipitate on cooling, but instead developed at temperature. This is due to the fact that $\mathrm{L}_{\mathrm{CaCrO}}$ dissolves very little $(<1$ at. \%) nickel or cobalt oxide: as the reaction front advances into the $\gamma$-phase, $\mathrm{Ni}$ and Co are rejected from the liquid and precipitate as oxide particles. Similarly, the solubility of $\mathrm{Al}_{2} \mathrm{O}_{3}$ in the chromate was measured by SEM-EDS to be quite low (1-2 at. \%), as also reported by Kaiser et al. [27]. This led to an Al:Cr elemental ratio of about 1:5, similar to that in the original $\gamma$ phase in $\mathrm{Ni}-30 \mathrm{Co}-33 \mathrm{Cr}-12 \mathrm{Al}-0.1 \mathrm{Y}$ and $\mathrm{Ni}-33 \mathrm{Co}-35 \mathrm{Cr}-7 \mathrm{Al}-0.1 \mathrm{Y}$. The conservation of this $\mathrm{Al}$ : $\mathrm{Cr}$ ratio indicates that the $\gamma$ phase was consumed in situ by the rapidly advancing reaction front. However, some change in the boundary conditions, such as a decelerating reaction front and associated accumulation of $\mathrm{Al}$ in the alloy at the metal/oxide interface, must occur to allow for the eventual establishment of an $\mathrm{Al}_{2} \mathrm{O}_{3}$ layer. The Cr-rich oxides observed at the reaction front in the non-passivated zones of the $100 \% \gamma$ alloy (Fig. 7) likely represent an intermediate stage between rapid liquid formation and the establishment of an $\mathrm{Al}_{2} \mathrm{O}_{3}$ layer.

Exactly how the alloy passivates remains unclear at this stage. Nevertheless, the implications of this reaction process are readily understood, in terms of alloy resistance to the severe degradation associated with liquid calcium chromate: metal loss should be minimized with a lower chromium content or a higher fraction of $\beta$. In particular, considerable resistance can be obtained by having a $\beta$ fraction sufficiently high for the $\beta$ phase to be continuous, as opposed to forming a dispersion in a $\gamma$ matrix, as schematically represented in Fig. 10 . The $\beta$-rich $\mathrm{Ni}-20 \mathrm{Co}-16 \mathrm{Cr}-23 \mathrm{Al}-$ $0.1 \mathrm{Y}$ did form a very small amount of $\mathrm{L}_{\mathrm{CaCrO}}$ and (Ni,Co)O (Fig. 3a); the large $\beta$ fraction $(57 \%)$ simply allowed the progression of the liquid phase to be undercut by an $\mathrm{Al}_{2} \mathrm{O}_{3}$ layer sooner than in the $\gamma$-rich alloys.

\subsection{Kinetics of $\mathrm{Al}_{2} \mathrm{O}_{3}$ growth at $1100{ }^{\circ} \mathrm{C}$}

The stage of rapid alloy consumption due to liquid chromate formation at $1100{ }^{\circ} \mathrm{C}$ was followed by a steady-state of slower reaction, which corresponded to the establishment of an inner continuous $\mathrm{Al}_{2} \mathrm{O}_{3}$ layer. However, this thermally growing $\mathrm{Al}_{2} \mathrm{O}_{3}$ reacted with the calcium and oxygen contained in $\mathrm{L}_{\mathrm{CaCrO}}$, or directly with the $\mathrm{CaO}$ deposit, to form $\mathrm{C}_{x} \mathrm{~A}_{y}$. Much like evaporation of $\mathrm{Cr}_{2} \mathrm{O}_{3}$ scales in wet atmospheres, consumption of the protective oxide has consequences on the reaction kinetics, which 
$\gamma$-rich alloy $\quad \beta$-rich alloy

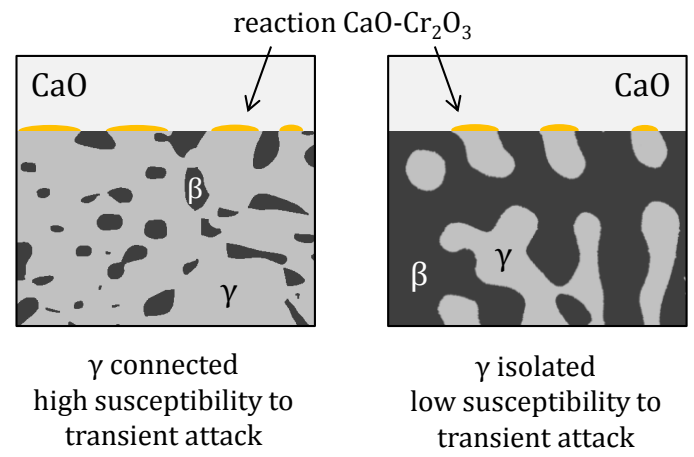

Figure 10: Schematics showing how the susceptibility for transient attack by $\mathrm{CaO}$ is determined by the distribution of the Cr-rich $\gamma$ phase in the alloy.

are considered in the following. Quite different from evaporation, destruction of the oxide in the present case occurred via a solid-state, diffusion-controlled process.

The case of $\mathrm{Ni}-20 \mathrm{Co}-16 \mathrm{Cr}-23 \mathrm{Al}-0.1 \mathrm{Y}$, where very little $\mathrm{L}_{\mathrm{CaCrO}}$ formed and the outermost $\mathrm{C}_{x} \mathrm{~A}_{y}$ layer was in contact with the $\mathrm{CaO}$ deposit, is considered first. Figure 11 shows a schematic of the reaction process. Calcium aluminate growth is known to be controlled by $\mathrm{Ca}^{2+}$ diffusion in the solid state [32-35]; its formation is therefore described to occur at the $\mathrm{Al}_{2} \mathrm{O}_{3} / \mathrm{C}_{x} \mathrm{~A}_{y}$ interface by the reaction

$$
x \mathrm{Ca}^{2+}+x \mathrm{O}^{2-}+y \mathrm{Al}_{2} \mathrm{O}_{3}=\mathrm{C}_{x} \mathrm{~A}_{y} .
$$

The oxygen and calcium necessary for this reaction are provided by the decomposition of $\mathrm{CaO}$ at the $\mathrm{CaO} / \mathrm{C}_{x} \mathrm{~A}_{y}$ interface:

$$
\mathrm{CaO}=\mathrm{Ca}^{2+}+\mathrm{O}^{2-} .
$$

Two processes contribute to net $\mathrm{Al}_{2} \mathrm{O}_{3}$ growth: (i) its destruction to form $\mathrm{C}_{x} \mathrm{~A}_{y}$ according to Eq. (2) at the $\mathrm{Al}_{2} \mathrm{O}_{3} / \mathrm{C}_{x} \mathrm{~A}_{y}$ interface, and (ii) its production by oxidation of aluminum contained in the metal substrate,

$$
2 \mathrm{Al}^{3+}+3 \mathrm{O}^{2-}=\mathrm{Al}_{2} \mathrm{O}_{3} .
$$

For the sake of simplicity, $\mathrm{Al}_{2} \mathrm{O}_{3}$ production is described to occur at the metal/oxide interface, with $\mathrm{O}^{2-}$ assumed to diffuse faster than $\mathrm{Al}^{3+}$. The choice of a mixed or predominantly outward growth mechanism would not change the resulting kinetics. As illustrated in Fig. 11, the oxygen necessary for $\mathrm{Al}_{2} \mathrm{O}_{3}$ growth is supplied by solid-state diffusion through $\mathrm{C}_{x} \mathrm{~A}_{y}$. This oxygen ultimately originates from the gas atmosphere. It is further assumed that the oxygen provided by decomposition of $\mathrm{CaO}$ is entirely consumed to form $\mathrm{C}_{x} \mathrm{~A}_{y}$. This prevents the accumulation of calcium or oxygen in $\mathrm{C}_{x} \mathrm{~A}_{y}$, and is realistic insofar as all known calcium aluminates are intermediate $x \mathrm{CaO}-y \mathrm{Al}_{2} \mathrm{O}_{3}$ compounds (Fig. 4a), in which the degree of oxidation of $\mathrm{Ca}$ and $\mathrm{Al}$ is not different from that in $\mathrm{CaO}$ and $\mathrm{Al}_{2} \mathrm{O}_{3}$, respectively. In the case of the $\gamma$-rich $\mathrm{Ni}-30 \mathrm{Co}-33 \mathrm{Cr}-12 \mathrm{Al}-0.1 \mathrm{Y}$ alloy, the $\mathrm{C}_{x} \mathrm{~A}_{y}$ layers are surmounted by liquid calcium chromate; it is assumed that the latter can rapidly provide the oxygen and 


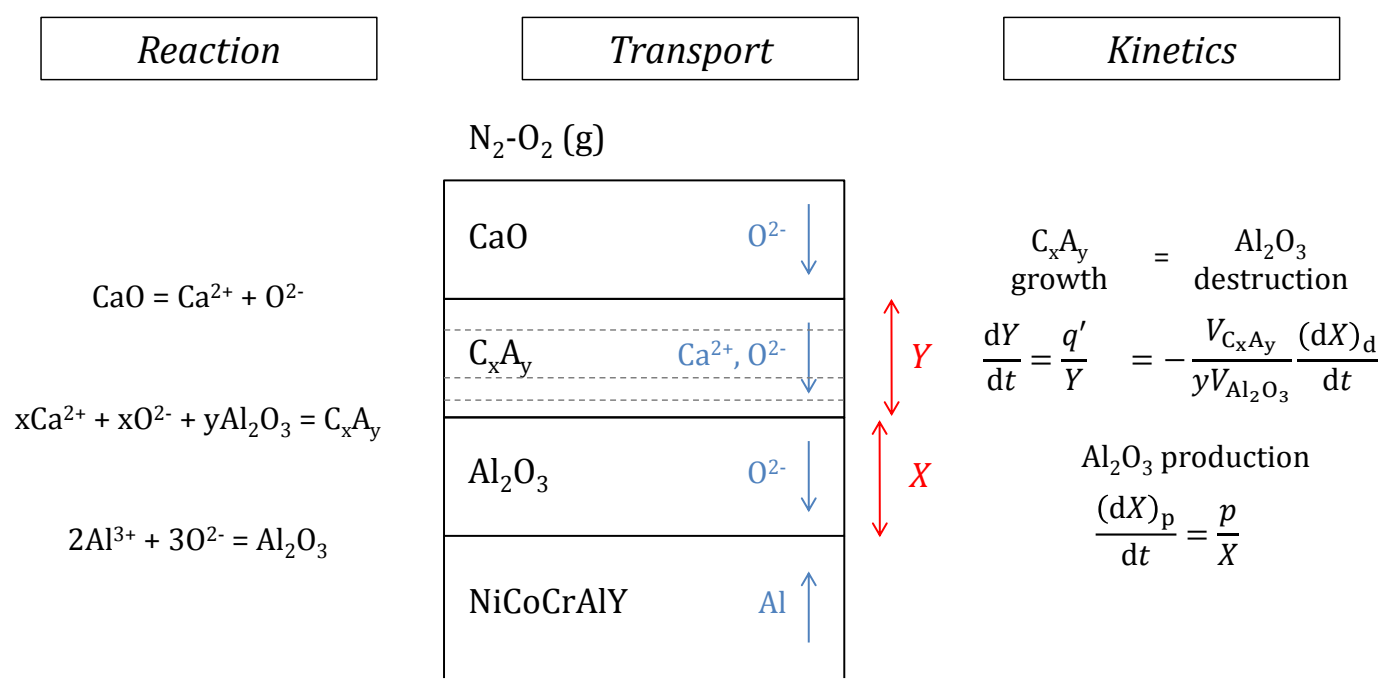

Figure 11: Schematic representation of the reactions and transport processes associated with the formation of calcium aluminate from $\mathrm{CaO}$ and thermally grown $\mathrm{Al}_{2} \mathrm{O}_{3}$. Variables are defined in text.

calcium required for $\mathrm{C}_{x} \mathrm{~A}_{y}$ and $\mathrm{Al}_{2} \mathrm{O}_{3}$ growth, and that this step is therefore not rate-limiting.

Several investigators have studied the growth kinetics of oxide scales that consist of multiple layers growing by diffusion of the same cation, taking into account the partitioning of the cation flux between the successive layers [36-41]. The present situation is slightly different in that it involves two types of cations, but it is equivalent if one considers the diffusion of oxygen instead. Provided that the degree of oxidation of aluminum and calcium does not change upon forming any of the aluminates from $\mathrm{CaO}$ and $\mathrm{Al}_{2} \mathrm{O}_{3}$, the present situation is a particular, simple case of the general formalism introduced by Yurek et al. [37] for two-layer structures. That treatment provided a relationship between the thickening constant measured for each layer in the multi-layer scale and the "intrinsic" constants that would be observed if a single-layer of each individual oxide had formed.

Published studies of calcium aluminate growth mostly concern powders, and the reported rate constants tend to vary significantly depending on the starting materials and the method used to assess the results. In the absence of consistent data in the literature, the present analysis will rely on experimental data obtained here. The following considers the relationship between the constants measured for $\mathrm{Al}_{2} \mathrm{O}_{3}$ and $\mathrm{C}_{x} \mathrm{~A}_{y}$ in the multi-layer structure and the constant for individual $\mathrm{Al}_{2} \mathrm{O}_{3}$ growth, measured in the absence of a deposit. Since the stoichiometry and relative thicknesses of the aluminates do not affect the flux of oxygen used for the oxidation reaction, the aluminate layers are gathered into a single layer of average stoichiometry $\mathrm{C}_{x} \mathrm{~A}_{y}$. Its thickening kinetics are described in accordance with the parabolic rate law,

$$
\frac{\mathrm{d} Y}{\mathrm{~d} t}=\frac{q^{\prime}}{Y},
$$

where $Y$ is the thickness of $\mathrm{C}_{x} \mathrm{~A}_{y}$ in the $\mathrm{Al}_{2} \mathrm{O}_{3}-\mathrm{C}_{x} \mathrm{~A}_{y}$ scale, and $q^{\prime}$ is the associated 
parabolic constant. Since $Y(t=0)=0$, Eq. (5) yields

$$
Y^{2}=2 q^{\prime} t
$$

Considering the mass balance underlying Eq. (2), the destruction of $\mathrm{Al}_{2} \mathrm{O}_{3}$ is written

$$
\frac{(\mathrm{d} X)_{\mathrm{d}}}{\mathrm{d} t}=-\frac{y V_{\mathrm{Al}_{2} \mathrm{O}_{3}}}{V_{\mathrm{C}_{x} \mathrm{~A}_{y}}} \frac{\mathrm{d} Y}{\mathrm{~d} t},
$$

where $V_{i}$ is the molar volume of phase $i$. Using the TGA data of Fig. 6, it can be shown that in the steady-state regime established in the absence of a deposit, $\mathrm{Al}_{2} \mathrm{O}_{3}$ grows according to parabolic kinetics. Previous findings discussed in Ref. [42] show that the rate-limiting step for $\mathrm{Al}_{2} \mathrm{O}_{3}$-scale thickening is grain-boundary diffusion of $\mathrm{O}^{2-}$ and $\mathrm{Al}^{3+}$. This still holds when there is concurrent $\mathrm{C}_{x} \mathrm{~A}_{y}$ formation, so long as the alloy can provide sufficient $\mathrm{Al}$ to sustain $\mathrm{Al}_{2} \mathrm{O}_{3}$ growth. Inasmuch as the constitution and predominant structure of $\mathrm{Al}_{2} \mathrm{O}_{3}$ grain boundaries remain unchanged, the instantaneous growth rate in a situation of production-destruction is inversely proportional to the oxide thickness, with the same constant as in the absence of a deposit. Thus the production term is written

$$
\frac{(\mathrm{d} X)_{\mathrm{p}}}{\mathrm{d} t}=\frac{p}{X}
$$

where $X$ is the thickness of $\mathrm{Al}_{2} \mathrm{O}_{3}$ in the $\mathrm{Al}_{2} \mathrm{O}_{3}-\mathrm{C}_{x} \mathrm{~A}_{y}$ scale and $p$ is the parabolic constant for exclusive oxidation.

The net $\mathrm{Al}_{2} \mathrm{O}_{3}$ growth is obtained by adding the two contributions, i.e., Eqs. (7) and (8):

$$
\frac{\mathrm{d} X}{\mathrm{~d} t}=\frac{(\mathrm{d} X)_{\mathrm{p}}}{\mathrm{d} t}+\frac{(\mathrm{d} X)_{\mathrm{d}}}{\mathrm{d} t}=\frac{p}{X}-\frac{y V_{\mathrm{Al}_{2} \mathrm{O}_{3}}}{V_{\mathrm{C}_{x} \mathrm{~A}_{y}}} \frac{\mathrm{d} Y}{\mathrm{~d} t}
$$

or, using Eqs. (5) and (6),

$$
\frac{\mathrm{d} X}{\mathrm{~d} t}=\frac{p}{X}-\alpha \frac{q^{\prime}}{\sqrt{2 q^{\prime} t}}
$$

where $\alpha=\frac{y V_{\mathrm{Al}_{2} \mathrm{O}_{3}}}{V_{\mathrm{C}_{x} \mathrm{~A}_{y}}}$. This equation is solved to yield

$$
\left\{\begin{array}{l}
X^{2}=2 p^{\prime} t \\
p^{\prime}=\frac{1}{2}\left[2 p+\alpha^{2} q^{\prime}-\alpha \sqrt{q^{\prime}\left(4 p+\alpha^{2} q^{\prime}\right)}\right] .
\end{array}\right.
$$

The form of Eq. (10) allows for another solution $p^{\prime \prime}=\frac{1}{2}\left[2 p+\alpha^{2} q^{\prime}+\alpha \sqrt{q^{\prime}\left(4 p+\alpha^{2} q^{\prime}\right)}\right]$, with $p^{\prime}<p<p^{\prime \prime}$. Since $\mathrm{Al}_{2} \mathrm{O}_{3}$ is being consumed by the reaction with the aluminate, $p^{\prime}$ is the appropriate solution. Noting that the valence of aluminum is the same in $\mathrm{Al}_{2} \mathrm{O}_{3}$ and $\mathrm{C}_{x} \mathrm{~A}_{y}$, the same expression for $p^{\prime}$ can be obtained from the general equations given by Yurek et al. [37]. Based on that treatment, the relationships between the constants measured in the $\mathrm{Al}_{2} \mathrm{O}_{3}-\mathrm{C}_{x} \mathrm{~A}_{y}$ scale and the constants for individual $\mathrm{Al}_{2} \mathrm{O}_{3}$ and $\mathrm{C}_{x} \mathrm{~A}_{y}$ growth are

$$
\begin{aligned}
p^{\prime} & =\frac{p}{1+\alpha \frac{Y}{X}} \\
q^{\prime} & =\frac{q}{1+\frac{1}{\alpha} \frac{X}{Y}}
\end{aligned}
$$


Table 2: Parabolic constants $\left(10^{-14} \mathrm{~cm}^{2} \mathrm{~s}^{-1}\right)$ for $\mathrm{Al}_{2} \mathrm{O}_{3}$ and $\mathrm{C}_{x} \mathrm{~A}_{y}$ growth in $\mathrm{Al}_{2} \mathrm{O}_{3}-\mathrm{C}_{x} \mathrm{~A}_{y}$ scales, and for exclusive $\mathrm{Al}_{2} \mathrm{O}_{3}$ growth, obtained from various methods (see text for details).

\begin{tabular}{lccc}
\hline & & $\mathrm{Ni}-20 \mathrm{Co}-16 \mathrm{Cr}-23 \mathrm{Al}-0.1 \mathrm{Y}$ & $\mathrm{Ni}-30 \mathrm{Co}-33 \mathrm{Cr}-12 \mathrm{Al}-0.1 \mathrm{Y}$ \\
\hline $\mathrm{Al}_{2} \mathrm{O}_{3}$ thickness & $p^{\prime}$ & 0.41 & 1.9 \\
$\mathrm{TGA}$ (no deposit) & $p$ & 11 & 13 \\
$\mathrm{C}_{x} \mathrm{~A}_{y}$ thickness & $q^{\prime}$ & 83 & 80 \\
Equation (11) & $p^{\prime}$ & 2.7 & 3.7 \\
TGA (with deposit) & $r^{\prime}$ & 25 & 24 \\
Equation (21) & $p^{\prime}$ & 4.5 & 6.9 \\
\hline
\end{tabular}

with the ratio of layer thicknesses in the multi-layer structure given by

$$
\frac{Y}{X}=\alpha \frac{q}{p}
$$

The analysis is now applied to the reactions of $\mathrm{Ni}-20 \mathrm{Co}-16 \mathrm{Cr}-23 \mathrm{Al}-0.1 \mathrm{Y}$ and $\mathrm{Ni}-30 \mathrm{Co}-33 \mathrm{Cr}-12 \mathrm{Al}-0.1 \mathrm{Y}$. For each alloy, the intrinsic oxidation rate $p$ is arrived at by fitting the TGA data measured with no $\mathrm{CaO}$ (Fig. 6), while $q^{\prime}$ is determined from $\mathrm{C}_{x} \mathrm{~A}_{y}$ thickness measurements (Fig. 5). The ratio $\alpha=y V_{\mathrm{Al}_{2} \mathrm{O}_{3}} / V_{\mathrm{C}_{x} \mathrm{~A}_{y}}$ is calculated as the average of values obtained for CA and $\mathrm{CA}_{2}$, which were found by SEM-EDS to constitute most of the $\mathrm{C}_{x} \mathrm{~A}_{y}$. Values of $p^{\prime}$ calculated with Eq. (11) are shown in Table 2, together with constants obtained from direct measurement of $\mathrm{Al}_{2} \mathrm{O}_{3}$ thickness in $\mathrm{Al}_{2} \mathrm{O}_{3}-\mathrm{C}_{x} \mathrm{~A}_{y}$ scales (Fig. 5). The latter are seen to be within an order of magnitude but significantly smaller than those obtained indirectly via Eq. (11), especially for the $\beta$-rich alloy. This will be discussed subsequently.

After evaluating reaction kinetics based on direct thickness measurements, $p^{\prime}$ is now calculated using TGA data (Fig. 6), which also reflect the rate at which the $\mathrm{Al}_{2} \mathrm{O}_{3}$ layer thickens. According to the description adopted here and represented in Fig. 11, the weight gain per unit of surface area recorded during reaction with $\mathrm{CaO}$ corresponds to the oxygen uptake necessary for $\mathrm{Al}_{2} \mathrm{O}_{3}$ production:

$$
\frac{\mathrm{d} m}{\mathrm{~d} t}=\frac{\mathrm{d} m_{\mathrm{O}}}{\mathrm{d} t}=\frac{\left(\mathrm{d} m_{\mathrm{O}}\right)_{\mathrm{p}}}{\mathrm{d} t} .
$$

No net weight gain arises from $\mathrm{C}_{x} \mathrm{~A}_{y}$ growth, as the calcium and oxygen forming the $x \mathrm{CaO}$ units come from the $\mathrm{CaO}$ deposit, and the aluminum and oxygen forming the $y \mathrm{Al}_{2} \mathrm{O}_{3}$ units come from the existing $\mathrm{Al}_{2} \mathrm{O}_{3}$. The net oxygen uptake is related to the quantity of $\mathrm{Al}_{2} \mathrm{O}_{3}$ that is produced through the mass balance underlying Eq. (4):

$$
\frac{1}{M_{\mathrm{O}}}\left(\mathrm{d} m_{\mathrm{O}}\right)_{\mathrm{p}}=\left(\mathrm{d} n_{\mathrm{O}}\right)_{\mathrm{p}}=3\left(\mathrm{~d} n_{\mathrm{Al}_{2} \mathrm{O}_{3}}\right)_{\mathrm{p}}
$$

where $M_{\mathrm{O}}$ is the atomic weight of oxygen. Combining Eqs. (15) and (16), and converting the quantity of $\mathrm{Al}_{2} \mathrm{O}_{3}$ into an equivalent thickness, one obtains

$$
\frac{\mathrm{d} m}{\mathrm{~d} t}=\frac{3 M_{\mathrm{O}}}{V_{\mathrm{Al}_{2} \mathrm{O}_{3}}} \frac{(\mathrm{d} X)_{\mathrm{p}}}{\mathrm{d} t} .
$$

Using the TGA data of Fig. 6, one can show that at steady-state, weight gains of both $\mathrm{Ni}-20 \mathrm{Co}-16 \mathrm{Cr}-23 \mathrm{Al}-0.1 \mathrm{Y}$ and $\mathrm{Ni}-30 \mathrm{Co}-33 \mathrm{Cr}-12 \mathrm{Al}-0.1 \mathrm{Y}$ in the presence of 
$\mathrm{CaO}$ obey a parabolic law

$$
m^{2}=2 s^{\prime} t
$$

where $s^{\prime}$ is the gravimetric constant. It follows from Eq. (17) that $\mathrm{Al}_{2} \mathrm{O}_{3}$ production also obeys parabolic kinetics, which is written

$$
\frac{(\mathrm{d} X)_{\mathrm{p}}}{\mathrm{d} t}=\frac{r^{\prime}}{\sqrt{2 r^{\prime} t}}
$$

where $r^{\prime}=s^{\prime}\left(V_{\mathrm{Al}_{2} \mathrm{O}_{3}} / 3 M_{\mathrm{O}}\right)^{2}$ is the parabolic constant related to the rate at which $\mathrm{Al}_{2} \mathrm{O}_{3}$ thickens by oxidation of the alloy in the $\mathrm{Al}_{2} \mathrm{O}_{3}-\mathrm{C}_{x} \mathrm{~A}_{y}$ structure. This production rate is inversely proportional to the layer thickness, Eq. (8), which yields

$$
\frac{p}{X}=\frac{r^{\prime}}{\sqrt{2 r^{\prime} t}} .
$$

Considering that $X(t=0)=0$, Eq. (20) is solved to provide

$$
\left\{\begin{array}{l}
X^{2}=2 p^{\prime} t \\
p^{\prime}=\frac{p^{2}}{r^{\prime}} .
\end{array}\right.
$$

Thus $p^{\prime}$ can be calculated from $r^{\prime}$ and $p$, which are obtained by fitting TGA data recorded with and without $\mathrm{CaO}$ deposit, respectively. The results are seen in Table 2 to be in reasonable agreement with the values obtained with Eq. (11), although slightly higher.

Two observations should be made from the $p^{\prime}$ values presented in Table 2. First, for a given alloy, a significant discrepancy exists between the values obtained with the three methods used. This is particularly the case for the $\beta$-rich alloy, where the value corresponding to direct thickness measurements is much lower than the calculated values. The difference is beyond possible experimental errors, and must instead reflect the incomplete satisfaction of the limiting assumptions made here. First, analysis by SEM-EDS showed small amounts (1-2 at. \%) of chromium in the $\mathrm{C}_{x} \mathrm{~A}_{y}$, and of aluminum in the $\mathrm{L}_{\mathrm{CaCrO}}$. This slightly affects the mass balance underlying Eq. (11) and the interpretation of the TGA data, via Eq. (16). Furthermore, some aspects of the complexities associated with $\mathrm{Al}_{2} \mathrm{O}_{3}$ growth were not accounted for in the present analysis. For instance, one aspect is related to the choice of boundary conditions: the oxygen activity at the $\mathrm{Al}_{2} \mathrm{O}_{3}$ surface was assumed to be the same whether calcium aluminates form or not, although some $p_{\mathrm{O}_{2}}$ gradient probably exists across the layers in the $\mathrm{Al}_{2} \mathrm{O}_{3}-\mathrm{C}_{x} \mathrm{~A}_{y}$ scale. This arguably does not affect $p^{\prime}$ significantly, inasmuch as $\mathrm{Al}_{2} \mathrm{O}_{3}$ predominantly exhibits n-type behavior, and its growth rate is little affected by the external $p_{\mathrm{O}_{2}}$ [42]. Further, oxidation both with and without $\mathrm{CaO}$ involves a transient stage, as shown by the TGA data in Fig. 6, which possibly comprises the formation of metastable $\mathrm{Al}_{2} \mathrm{O}_{3}$ polymorphs, base-metal oxides or $\mathrm{L}_{\mathrm{CaCrO}}$ prior to the establishment of $\alpha-\mathrm{Al}_{2} \mathrm{O}_{3}$ and $\mathrm{C}_{x} \mathrm{~A}_{y}$ layers. One can show that the extent of these processes does not directly affect the thickening rate achieved during steady-state. (Specifically, using equations of the form $\left(x-x_{i}\right)^{2}=2 k\left(t-t_{i}\right)$ or $x^{2}-x_{i}^{2}=2 k\left(t-t_{i}\right)$ to describe $\mathrm{Al}_{2} \mathrm{O}_{3}$ or $\mathrm{C}_{x} \mathrm{~A}_{y}$ growth does not change the expression giving $p^{\prime}$ in Eq. (11) for sufficiently long reaction times.) However, in accordance with the analysis of Brumm and Grabke [31], aspects of transient oxidation such as the time needed for the $\theta \rightarrow \alpha$ transformation 
do have an influence on the microstructure of $\mathrm{Al}_{2} \mathrm{O}_{3}$, in particular its grain size, and therefore affect growth rates observed on the longer term. In this respect, because of the p-type nature of $\theta-\mathrm{Al}_{2} \mathrm{O}_{3}$ [43-45], a reduced $p_{\mathrm{O}_{2}}$ at the oxide surface in the presence of $\mathrm{C}_{x} \mathrm{~A}_{y}$ could have an indirect effect on the $\alpha-\mathrm{Al}_{2} \mathrm{O}_{3}$ eventually established, by slowing the growth of the metastable polymorph. Due to its high reactivity, the presence of $\mathrm{CaO}$ certainly had an impact on the transient stage of the reaction, as evident in Fig. 6, although potential effects on $\mathrm{Al}_{2} \mathrm{O}_{3}$ microstructure were beyond the scope of this investigation.

A second observation arising from the data gathered in Table 2 is that a significant difference exists between the $p^{\prime}$ values obtained for the two alloys, which is not accounted for in the present analysis. This is most evident when considering $p^{\prime}$ from direct $\mathrm{Al}_{2} \mathrm{O}_{3}$ thickness measurements. Similarly, the $\mathrm{C}_{x} \mathrm{~A}_{y}$-to- $\mathrm{Al}_{2} \mathrm{O}_{3}$ thickness ratio, while approximately constant with time for each alloy as expected for diffusion-controlled growth processes, was found to be quite different for the two alloys: $12.8 \pm 0.8$ for $\mathrm{Ni}-20 \mathrm{Co}-16 \mathrm{Cr}-23 \mathrm{Al}-0.1 \mathrm{Y}$, versus $6.2 \pm 0.2$ for $\mathrm{Ni}-30 \mathrm{Co}-$ $33 \mathrm{Cr}-12 \mathrm{Al}-0.1 \mathrm{Y}$. This could possibly be due to a difference in the constitution of the $\mathrm{C}_{x} \mathrm{~A}_{y}$ scale, as varying relative thicknesses would affect the average scale stoichiometry. This could not be assessed with sufficient accuracy because of the non-uniform, locally rumpled morphology of the reaction product. Another potential effect is related to the presence of liquid calcium chromate. In the case of the $\gamma$-rich alloy, the calcium and oxygen required for $\mathrm{C}_{x} \mathrm{~A}_{y}$ and $\mathrm{Al}_{2} \mathrm{O}_{3}$ growth must be provided by the $\mathrm{L}_{\mathrm{CaCrO}}$ which forms a thick and continuous layer. If ionic transport in the liquid is not sufficiently rapid, it could limit the rate of $\mathrm{C}_{x} \mathrm{~A}_{y}$ growth, and allow a relatively thicker $\mathrm{Al}_{2} \mathrm{O}_{3}$ to persist. Furthermore, a slow transport would also involve a local chromium enrichment in the liquid, and, since the latter occupies a small composition range at $1100{ }^{\circ} \mathrm{C}$ (Fig. 4b), this could result in the precipitation of $\mathrm{CaCr}_{2} \mathrm{O}_{4}$. The phase transformation would involve a partial reduction of chromium (the liquid contains a mixture of $\mathrm{Cr}$ III and $\mathrm{Cr}$ VI, while $\mathrm{CaCr}_{2} \mathrm{O}_{4}$ contains only $\mathrm{Cr}$ III), which would affect oxygen both in the mass balance underlying Eq. (11) and in the interpretation of the TGA data, via Eq. (15). Again the constitution of the $\mathrm{L}_{\mathrm{CaCrO}}$ could not be characterized with the degree of accuracy required because of experimental limitations.

Overall, the present results indicate that beyond a reduction in thickness, the growth mechanism of $\mathrm{Al}_{2} \mathrm{O}_{3}$ is affected by the reaction with $\mathrm{CaO}$. The details of the associated processes, as well as the role played by alloy composition, are outside the scope of the present paper and deserve further investigation. Yet, the present analysis is useful in that it provides a semi-quantitative evaluation of the effect of $\mathrm{CaO}$ on the rate of $\mathrm{Al}$ consumption. In essence, as $\mathrm{Al}_{2} \mathrm{O}_{3}$ reacts to form $\mathrm{C}_{x} \mathrm{~A}_{y}$, its thickness is reduced, and so is its ability to act as a diffusion barrier: the instantaneous oxidation rate $p / X$ increases. This rate is expressed as $(\mathrm{d} X)_{\mathrm{p}} / \mathrm{d} t=p / \sqrt{2 p^{\prime} t}$, and since $p^{\prime}<p$, it is indeed larger than its $\mathrm{CaO}$-free counterpart, $p / \sqrt{2 p t}$. Another metric that can be used to characterize $\mathrm{Al}$ consumption is the rate of $\beta$ dissolution. Due to the larger oxidation rate, $\beta$ is dissolved at a greater rate in the presence of $\mathrm{CaO}$, as seen in Fig. 5. 


\subsection{Effect of temperature on $\mathrm{Al}$ consumption in the presence of $\mathrm{CaO}$}

We now consider the effect of the reaction with $\mathrm{CaO}$ on the ability of a given alloy to maintain an $\mathrm{Al}_{2} \mathrm{O}_{3}$ layer, using Wagner's [46] criterion for sustained external scaling. Briefly, this is based on the principle that external $\mathrm{Al}_{2} \mathrm{O}_{3}$ growth can be maintained if the outward $\mathrm{Al}$ flux in the metal at the interface with the oxide matches the flux required for the oxide to grow. A maximum flux is obtained in the alloy when the interfacial $\mathrm{Al}$ content is set to zero, which in turn defines a minimum bulk concentration, $N_{\mathrm{Al}}^{*}$. Since the flux of Al consumed by scale growth is related to the instantaneous oxide production rate, the above analysis suggests that taking into account the reaction with $\mathrm{CaO}$ will amount to replacing the oxidation constant $p$ by the ratio $p^{2} / p^{\prime}$ in calculating $N_{\mathrm{Al}}^{*}$.

Under the assumptions of parabolic oxidation kinetics and of a constant $\mathrm{Al}$ diffusion coefficient in the alloy $\left(D_{\mathrm{Al}}\right)$ in the composition range of interest, $N_{\mathrm{Al}}^{*}$ is given by $[46]$

$$
N_{\mathrm{Al}}^{*}=F\left(\sqrt{\frac{1}{2} \frac{k_{\mathrm{c}}}{D_{\mathrm{Al}}}}\right)
$$

where $F$ is the auxiliary function defined by $F(u)=\sqrt{\pi} u(1-\operatorname{erf} u) \exp \left(u^{2}\right)$ and $k_{\mathrm{c}}$ the parabolic constant for metal recession, defined by $d^{2}=2 k_{\mathrm{c}} t$ with $d$ the depth of the metal/oxide interface relative to the original alloy surface. In a situation of individual $\mathrm{Al}_{2} \mathrm{O}_{3}$ growth, the mass balance on the aluminum contained in the oxide scale is written

$$
\frac{2 X}{V_{\mathrm{Al}_{2} \mathrm{O}_{3}}}=\frac{d}{V_{\mathrm{a}}}
$$

with $V_{\mathrm{a}}$ the molar volume of the alloy, which yields a simple relationship between $k_{\mathrm{c}}$ and $p$

$$
k_{\mathrm{c}}=\left(\frac{2 V_{\mathrm{a}}}{V_{\mathrm{Al}_{2} \mathrm{O}_{3}}}\right)^{2} p .
$$

This is now introduced in Eq. (22) to give

$$
N_{\mathrm{Al}}^{*}=F\left(\frac{2 V_{\mathrm{a}}}{V_{\mathrm{Al}_{2} \mathrm{O}_{3}}} \sqrt{\frac{p}{2 D_{\mathrm{Al}}}}\right) .
$$

When $\mathrm{Al}_{2} \mathrm{O}_{3}$ reacts with $\mathrm{CaO}$ to form calcium aluminates, the mass balance of Eq. (23) becomes

$$
\frac{2 X}{V_{\mathrm{Al}_{2} \mathrm{O}_{3}}}+\frac{2 y Y}{V_{\mathrm{C}_{x} \mathrm{~A}_{y}}}=\frac{d}{V_{\mathrm{a}}}
$$

Using Eqs. (6) and (11), Y can be given as

$$
Y=\frac{V_{\mathrm{C}_{x} \mathrm{~A}_{y}}}{y V_{\mathrm{Al}_{2} \mathrm{O}_{3}}}\left(\sqrt{2 \frac{p}{p^{\prime}}} t-X\right)
$$

and the relationship giving $k_{\mathrm{c}}$ from measurable constants becomes

$$
k_{\mathrm{c}}=\left(\frac{2 V_{\mathrm{a}}}{V_{\mathrm{Al}_{2} \mathrm{O}_{3}}}\right)^{2} \frac{p^{2}}{p^{\prime}}
$$


which finally yields

$$
N_{\mathrm{Al}}^{*}=F\left(\frac{2 V_{\mathrm{a}}}{V_{\mathrm{Al}_{2} \mathrm{O}_{3}}} \sqrt{\frac{p^{2} / p^{\prime}}{2 D_{\mathrm{Al}}}}\right) .
$$

A comparison between Eqs. (24) and (28) confirms that changing from an individual $\mathrm{Al}_{2} \mathrm{O}_{3}$ scale to a multi-layer $\mathrm{Al}_{2} \mathrm{O}_{3}-\mathrm{C}_{x} \mathrm{~A}_{y}$ scale amounts to replacing $p$ by $p^{2} / p^{\prime}$ when considering the flux of $\mathrm{Al}$ incorporated in the reaction product.

This analysis is now used to study the effect of a varying temperature on the reaction of $\mathrm{Ni}-30 \mathrm{Co}-27 \mathrm{Cr}-12 \mathrm{Al}-0.1 \mathrm{Y}$ with $\mathrm{Al}_{2} \mathrm{O}_{3}-\mathrm{CaO}$ deposits. No measured value of $p$ or $p^{\prime}$ is available for this alloy; instead, $N_{\mathrm{Al}}^{*}$ is evaluated as follows. The constant $p$ is taken from data by Brumm and Grabke [31] for $\alpha$ and $\theta-\mathrm{Al}_{2} \mathrm{O}_{3}$ growth on NiAlCr alloys, using activation energies of 350 and $231 \mathrm{~kJ} / \mathrm{mol}$, respectively. In the absence of direct data, $q$ is first calculated at $1100{ }^{\circ} \mathrm{C}$ from Eqs. (13) and (14) using $q^{\prime}$ measured here for $\mathrm{Ni}-30 \mathrm{Co}-33 \mathrm{Cr}-12 \mathrm{Al}-0.1 \mathrm{Y}$ (Table 2) and $p$ for $\alpha-\mathrm{Al}_{2} \mathrm{O}_{3}$ in Ref. [31]. Activation energies reported in the literature for the growth of calcium aluminates vary widely [33], with most values in the $150-250 \mathrm{~kJ} / \mathrm{mol}$ range [35]; the median $200 \mathrm{~kJ} / \mathrm{mol}$ is used here, in good agreement with results reported in Refs. [32,34]. Values of $q$ at varying temperatures are then calculated from $q$ at $1100{ }^{\circ} \mathrm{C}$, based on the Arrhenius equation. Constants $p^{\prime}$ and $q^{\prime}$ are then obtained for each of $\alpha$ and $\theta-\mathrm{Al}_{2} \mathrm{O}_{3}$ using Eqs. (12-14) and the constants for individual $\mathrm{Al}_{2} \mathrm{O}_{3}$ $(p)$ and $\mathrm{C}_{x} \mathrm{~A}_{y}(q)$ growth. Interdiffusion in a 5-component, 2-phase alloy system is complex. Since $\beta$ is quite rapidly depleted from the subsurface of the $\gamma$-rich alloys, only diffusion in $\gamma$ is considered. Nesbitt and Heckel [47] published experimental interdiffusion data for the ternary $\mathrm{Ni}-\mathrm{Cr}-\mathrm{Al}$ system, including a regression equation allowing interdiffusion coefficients to be calculated as a function of alloy composition. Chromium concentration gradients were seen to have little effect on Al diffusion, such that the main term $\tilde{D}_{\mathrm{Al}, \mathrm{Al}}^{\mathrm{Ni}}$ was prevalent. At $1100{ }^{\circ} \mathrm{C}$, replacing $\mathrm{Co}$ by $\mathrm{Ni}$ and ignoring Y, one calculates $\tilde{D}_{\mathrm{Al}, \mathrm{Al}}^{\mathrm{Ni}}=3.4 \times 10^{-10} \mathrm{~cm}^{2} \mathrm{~s}^{-1}$ for the nominal composition $(27 \mathrm{Cr}, 12 \mathrm{Al})$, and $\tilde{D}_{\mathrm{Al}, \mathrm{Al}}^{\mathrm{Ni}}=1.1 \times 10^{-10} \mathrm{~cm}^{2} \mathrm{~s}^{-1}$ for an alloy fully depleted of its Al. Equation (29) is based on a constant diffusion coefficient; the average value $\tilde{D}_{\mathrm{Al}, \mathrm{Al}}^{\mathrm{Ni}}=2 \times 10^{-10} \mathrm{~cm}^{2} \mathrm{~s}^{-1}$ is chosen as an approximation. This value is consistent with other experimental and calculated values for dilute $\mathrm{NiCrAl}$ alloys at $1100{ }^{\circ} \mathrm{C}$ gathered in Ref. [48]. The activation energy for $\tilde{D}_{\mathrm{Al}, \mathrm{Al}}^{\mathrm{Ni}}, 288 \mathrm{~kJ} / \mathrm{mol}$, is taken from Ref. [47].

Minimum Al concentrations calculated using Eq. (29) are plotted as a function of temperature in Fig. 12 for both $\alpha$ and $\theta-\mathrm{Al}_{2} \mathrm{O}_{3}$ growth, with and without $\mathrm{CaO}$ reaction. All predicted $N_{\mathrm{Al}}^{*}$ values are below the alloy nominal Al content (12 at. \%). Considering $\alpha-\mathrm{Al}_{2} \mathrm{O}_{3}$ at $1100{ }^{\circ} \mathrm{C}$, the reaction with $\mathrm{CaO}$ leads to a relatively small increase of $N_{\mathrm{Al}}^{*}$, from 1.2 at. \% with no deposit to 2.8 at. \% with $\mathrm{CaO}$. This is consistent with the observed ability of $\mathrm{Ni}-30 \mathrm{Co}-27 \mathrm{Cr}-12 \mathrm{Al}-0.1 \mathrm{Y}$ to maintain an external $\mathrm{Al}_{2} \mathrm{O}_{3}$ layer at this temperature. For $\alpha-\mathrm{Al}_{2} \mathrm{O}_{3}$ reaction with $\mathrm{CaO}$, the $900{ }^{\circ} \mathrm{C}$ value of $N_{\mathrm{Al}}^{*}, 4.9$ at. \%, is higher than the $1100{ }^{\circ} \mathrm{C}$ value, but still relatively low. This indicates that the decrease in the alloy diffusion rate is partly compensated by the slowing of diffusion in $\mathrm{Al}_{2} \mathrm{O}_{3}$ and $\mathrm{C}_{x} \mathrm{~A}_{y}$. However, PSLS measurements (Fig. 9) showed that $\theta-\mathrm{Al}_{2} \mathrm{O}_{3}$ was still present in significant amounts after $50 \mathrm{~h}$ at $900^{\circ} \mathrm{C}$, which suggests that the metastable polymorph controlled the oxidation rate for an extended period at this temperature. Indeed, several investigators [30, 31, 


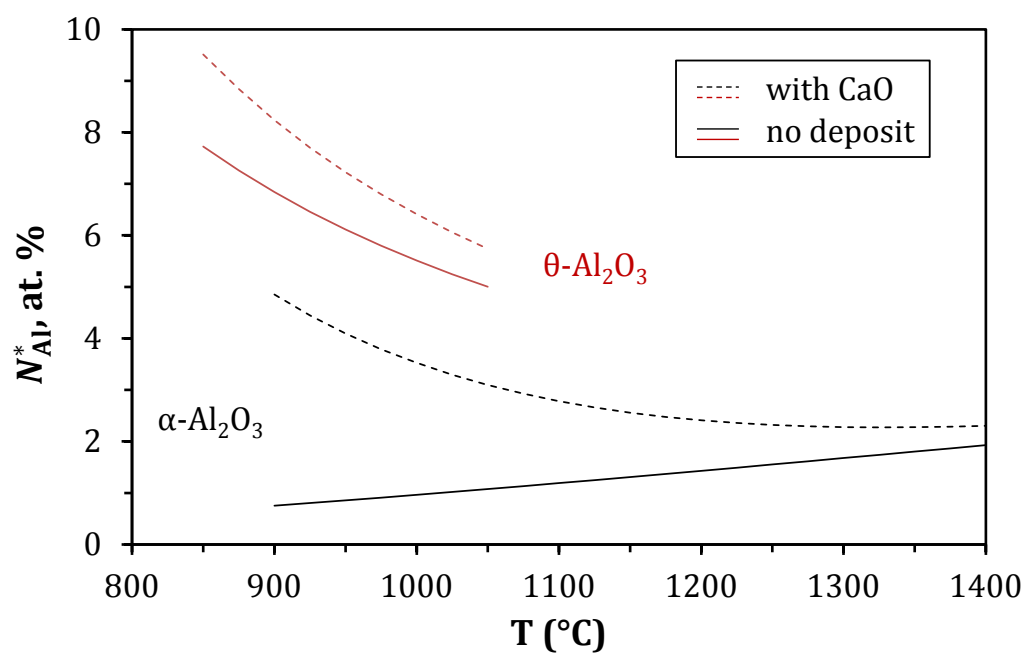

Figure 12: Minimum bulk $\mathrm{Al}$ content to maintain external $\mathrm{Al}_{2} \mathrm{O}_{3}$ growth with and without $\mathrm{CaO}$ reaction as a function of temperature. Calculated from Eqs. (25, 29), and parameters described in text.

$49,50]$ have shown that a temperature decrease from 1100 to $900{ }^{\circ} \mathrm{C}$ considerably delayed the $\theta \rightarrow \alpha$ transition. The value of $N_{\mathrm{Al}}^{*}$ calculated for $\theta-\mathrm{Al}_{2} \mathrm{O}_{3}$ reaction with $\mathrm{CaO}$ at $900{ }^{\circ} \mathrm{C}, 8.1$ at. \%, is significantly higher than that obtained for $\alpha-\mathrm{Al}_{2} \mathrm{O}_{3}$.

Uncertainties in the activation energies and the limiting assumptions used here are such that predicted $N_{\mathrm{Al}}^{*}$ values should be regarded as rough estimates. Nevertheless, the trends are valid and indicate that reaction with $\mathrm{CaO}$ will be significantly more severe in terms of $\mathrm{Al}$ consumption, relative to its availability at the metal/oxide interface, at $900{ }^{\circ} \mathrm{C}$ than at $1100{ }^{\circ} \mathrm{C}$. This is mainly due to the persistence of $\theta$ $\mathrm{Al}_{2} \mathrm{O}_{3}$ at the lower temperature. These observations are consistent with the observed failure of $\mathrm{Ni}-30 \mathrm{Co}-27 \mathrm{Cr}-12 \mathrm{Al}-0.1 \mathrm{Y}$ to passivate in the presence of $\mathrm{CaO}$ at $900{ }^{\circ} \mathrm{C}$.

The above analysis neglects the multi-phase nature of the alloys studied here. Compositional changes in oxidizing multi-phase alloys have been studied in the past [51-53]. Applying a diffusional analysis to $\beta-\gamma$ alloys shows that for a given bulk composition, the interfacial aluminum flux in steady-state conditions is greater when $\gamma$ contains more $\mathrm{Al}$ and the volume fraction of $\beta$ is correspondingly smaller. This is particularly evident using the analytical method of Ref. [51], as the minimum bulk concentration to maintain $\mathrm{Al}_{2} \mathrm{O}_{3}$ scaling according to Wagner's criterion, i.e., $N_{\mathrm{Al}}^{*}$ in Eq. (22), is to be replaced by the expression $\sqrt{N_{\mathrm{Al}}^{\gamma}\left[N_{\mathrm{Al}}^{\gamma}+2 f_{\beta}\left(N_{\mathrm{Al}}^{\beta}-N_{\mathrm{Al}}^{\gamma}\right)\right]}$, where $N_{\mathrm{Al}}^{i}$ is the $\mathrm{Al}$ mole fraction in phase $i$ and $f_{\beta}$ is the volume fraction of $\beta$. In the case of the $\mathrm{Ni}-30 \mathrm{Co}-27 \mathrm{Cr}-12 \mathrm{Al}-0.1 \mathrm{Y}$ alloy, as the temperature decreases, $f_{\beta}$ increases, which is compensated by a decrease in $N_{\mathrm{Al}}^{\gamma}$, from 9.7 at. $\%$ at $1100{ }^{\circ} \mathrm{C}$ to 7.3 at. $\%$ at $900{ }^{\circ} \mathrm{C}$ (measured by SEM-EDS). This results in a reduced interfacial $\mathrm{Al}$ flux, and further weighs against the alloy ability to sustain $\mathrm{Al}_{2} \mathrm{O}_{3}$ growth at the lower temperature. 


\section{Conclusions}

Two-phase $\beta-\gamma$ MCrAlY alloys exposed to $\mathrm{CaO}$ at $1100{ }^{\circ} \mathrm{C}$ were found to suffer significantly more degradation than in the absence of a deposit. The reaction with $\mathrm{CaO}$ proceeded according to two distinct mechanisms. During the initial stage, formation of a liquid calcium chromate led to the rapid consumption of the $\mathrm{Cr}$-rich $\gamma$-phase. The extent of degradation was particularly important for a single-phase $\gamma$ composition, and was significantly reduced by increasing the alloy $\beta$ fraction. In a subsequent stage, a continuous $\mathrm{Al}_{2} \mathrm{O}_{3}$ layer established at the base of the scale, which led to a much lower oxidation rate. However, the protective oxide reacted with $\mathrm{CaO}$ to form calcium aluminates, and as its thickness was reduced, the instantaneous oxidation rate was higher than in the absence of a deposit.

Analysis of the reaction kinetics of this steady-state regime, where $\mathrm{Al}_{2} \mathrm{O}_{3}$ is simultaneously produced by oxidation of the alloy and destructed by solid-state reaction with $\mathrm{CaO}$, allowed growth rates obtained by thickness-measurement and gravimetric methods to be compared. The agreement was generally good, although some discrepancy existed, which was discussed in terms of possible changes to $\mathrm{Al}_{2} \mathrm{O}_{3}$ growth mechanism due to the reaction with $\mathrm{CaO}$. The analysis also led to evaluate the effect of $\mathrm{CaO}$ reaction on the flux of aluminum required to sustain external $\mathrm{Al}_{2} \mathrm{O}_{3}$ growth. The temperature evolution of aluminum consumption was studied by considering the activation energies for $\mathrm{Al}$ diffusion in the alloy, and $\mathrm{Al}_{2} \mathrm{O}_{3}$ and calcium aluminate growth. A temperature decrease to $900{ }^{\circ} \mathrm{C}$ was found to be detrimental to the kinetic stability of the protective oxide, mainly due to the longer persistence of the metastable and faster growing $\theta-\mathrm{Al}_{2} \mathrm{O}_{3}$. Failure to maintain an external $\mathrm{Al}_{2} \mathrm{O}_{3}$ scale resulted for an Al-lean alloy in internal oxidation of $\mathrm{Al}$, and formation of a Cr-rich oxide scale. This did not have as severe consequences as at $1100{ }^{\circ} \mathrm{C}$ since $900{ }^{\circ} \mathrm{C}$ is below the calcium chromate eutectic.

\section{Acknowledgements}

This work was supported by the Department of Energy through the University Turbine Systems Research (UTSR) Program run by the National Energy Technology Laboratory, Award Number DE-FE0007271, Seth Lawson, Project Manager. The authors thank Wei Zhao and Juan Manuel Alvarado Orozco for useful discussions on some aspects of this work.

\section{References}

[1] G. Goward, Progress in coatings for gas turbine airfoils, Surface and Coatings Technology 108-109 (1998) pp. 73-79. doi: 10.1016/S0257-8972(98)00667-7.

[2] J. R. Nicholls, Designing oxidation-resistant coatings, JOM 52 (2000) pp. 28-35. doi: 10.1007/s11837-000-0112-2.

[3] A. G. Evans, D. R. Mumm, J. W. Hutchinson, G. H. Meier and F. S. Pettit, Mechanisms controlling the durability of thermal barrier coatings, Progress in Materials Science 46 (2001) pp. 505-553. doi: 10.1016/S0079-6425(00)00020-7.

[4] B. Gleeson, Thermal barrier coatings for aeroengine applications, Journal of Propulsion and Power 22 (2006) pp. 375-383. doi: 10.2514/1.20734. 
[5] A. G. Evans, D. R. Clarke and C. G. Levi, The influence of oxides on the performance of advanced gas turbines, Journal of the European Ceramic Society 28 (2008) pp. 1405-1419. doi: 10.1016/j.jeurceramsoc.2007.12.023.

[6] D. R. Clarke, M. Oechsner and N. P. Padture, Thermal-barrier coatings for more efficient gas-turbine engines, MRS Bulletin 37 (2012) pp. 891-902. doi: $10.1557 / \mathrm{mrs} .2012 .232$.

[7] R. Darolia, Thermal barrier coatings technology: critical review, progress update, remaining challenges and prospects, International Materials Reviews 58 (2013) pp. 315-348. doi: 10.1179/1743280413y.0000000019.

[8] J. L. Smialek, F. A. Archer and R. G. Garlick, Turbine airfoil degradation in the persian gulf war, JOM 46 (1994) pp. 39-41. doi: 10.1007/BF03222663.

[9] M. P. Borom, C. A. Johnson and L. A. Peluso, Role of environmental deposits and operating surface temperature in spallation of air plasma sprayed thermal barrier coatings, Surface and Coatings Technology 86 (1996) pp. 116-126. doi: 10.1016/s0257-8972(96)02994-5.

[10] C. Mercer, S. Faulhaber, A. Evans and R. Darolia, A delamination mechanism for thermal barrier coatings subject to calcium-magnesium-aluminosilicate (CMAS) infiltration, Acta Materialia 53 (2005) pp. 1029-1039. doi: 10.1016/j.actamat.2004.11.028.

[11] S. Kramer, J. Yang, C. G. Levi and C. A. Johnson, Thermochemical interaction of thermal barrier coatings with molten $\mathrm{CaO}-\mathrm{MgO}-\mathrm{Al}_{2} \mathrm{O}_{3}-\mathrm{SiO}_{2}$ (CMAS) deposits, Journal of the American Ceramic Society 89 (2006) pp. 3167-3175. doi: 10.1111/j.1551-2916.2006.01209.x.

[12] C. G. Levi, J. W. Hutchinson, M.-H. Vidal-Setif and C. A. Johnson, Environmental degradation of thermal-barrier coatings by molten deposits, MRS Bulletin 37 (2012) pp. 932-941. doi: 10.1557/mrs.2012.230.

[13] Clean Coal Technology Topical Report Number 24, NETL (US Department of Energy, August 2006).

[14] V. Nagarajan, R. D. Smith and I. G. Wright, Influence of solid-state CaS-CaO-CaSO 4 deposits on corrosion of high-temperature alloys in simulated FBC environments, Oxidation of Metals 31 (1989) pp. 325-340. doi: 10.1007/BF00846692.

[15] K.-Y. Jung, F. S. Pettit and G. H. Meier, The effect of Ca-rich deposits on the high temperature degradation of coated and uncoated superalloys, Materials Science Forum 595-598 (2008) pp. 805-812. doi: 10.4028/www.scientific.net/MSF.595-598.805.

[16] K. T. Chiang, G. H. Meier and R. A. Perkins, The effects of deposits of $\mathrm{CaO}, \mathrm{CaSO}_{4}$, and $\mathrm{MgO}$ on the oxidation of several $\mathrm{Cr}_{2} \mathrm{O}_{3}$-forming and $\mathrm{Al}_{2} \mathrm{O}_{3}$ forming alloys, Journal of Materials for Energy Systems 6 (1984) pp. 71-86. doi: $10.1007 / \mathrm{BF} 02833417$.

[17] W. Braue, Environmental stability of the YSZ layer and the YSZ/TGO interface of an in-service EB-PVD coated high-pressure turbine blade, Journal of Materials Science 44 (2009) pp. 1664-1675. doi: 10.1007/s10853-008-3215-8. 
[18] W. Braue and P. Mechnich, Recession of an EB-PVD YSZ coated turbine blade by $\mathrm{CaSO}_{4}$ and $\mathrm{Fe}$, Ti-rich CMAS-type deposits, Journal of the American Ceramic Society 94 (2011) pp. 4483-4489. doi: 10.1111/j.1551-2916.2011.04747.x.

[19] I. Wright and T. Gibbons, Recent developments in gas turbine materials and technology and their implications for syngas firing, International Journal of Hydrogen Energy 32 (2007) pp. 3610-3621. doi: 10.1016/j.ijhydene.2006.08.049.

[20] S. Sridhar, P. Rozzelle, B. Morreale and D. Alman, Materials challenges for advanced combustion and gasification fossil energy systems, Metallurgical and Materials Transactions A 42 (2011) pp. 871-877. doi: 10.1007/s11661-011-0627$\mathrm{x}$.

[21] B. A. Pint, High-temperature corrosion in fossil fuel power generation: Present and future, JOM 65 (2013) pp. 1024-1032. doi: 10.1007/s11837-013-0642-z.

[22] M. H. Sahraei, D. McCalden, R. Hughes and L. Ricardez-Sandoval, A survey on current advanced IGCC power plant technologies, sensors and control systems, Fuel 137 (2014) pp. 245-259. doi: 10.1016/j.fuel.2014.07.086.

[23] Materials Preparation Center, Ames Laboratory, US DOE Basic Energy Sciences, Ames, IA, USA, available from: www.ameslab.gov/mpc.

[24] C. A. Schneider, W. S. Rasband and K. W. Eliceiri, NIH image to ImageJ: 25 years of image analysis, Nature Methods 9 (2012) pp. 671-675. doi: 10.1038/nmeth.2089.

[25] V. K. Tolpygo and D. R. Clarke, Microstructural study of the theta-alpha transformation in alumina scales formed on nickel-aluminides, Materials at High Temperatures 17 (2000) pp. 59-70. doi: 10.1179/mht.2000.011.

[26] E. Levin, C. Robbins and H. McMurdie, Phase diagrams for ceramists vol. 1. The American Ceramic Society, Columbus, OH (1964).

[27] A. Kaiser, B. Sommer and E. Woermann, The system $\mathrm{CaO}-\mathrm{CaCr}_{2} \mathrm{O}_{4}-\mathrm{CaAl}_{2} \mathrm{O}_{4}$ in air and under mildly reducing conditions, Journal of the American Ceramic Society 75 (1992) pp. 1463-1471. doi: 10.1111/j.1151-2916.1992.tb04211.x.

[28] D. Monceau and B. Pieraggi, Determination of parabolic rate constants from a local analysis of mass-gain curves, Oxidation of Metals 50 (1998) pp. 477-493. doi: $10.1023 / \mathrm{a}: 1018860909826$.

[29] H. Hindam and D. P. Whittle, Microstructure, adhesion and growth kinetics of protective scales on metals and alloys, Oxidation of Metals 18 (1982) pp. 245284. doi: 10.1007/BF00656571.

[30] G. C. Rybicki and J. L. Smialek, Effect of the $\theta-\alpha-\mathrm{Al}_{2} \mathrm{O}_{3}$ transformation on the oxidation behavior of $\beta$-NiAl+Zr, Oxidation of Metals 31 (1989) pp. 275-304. doi: $10.1007 / \mathrm{bf00846690.}$

[31] M. W. Brumm and H. J. Grabke, The oxidation behavior of NiAl. 1. Phasetransformations in the alumina scale during oxidation of $\mathrm{NiAl}$ and $\mathrm{NiAl}$ Cr alloys, Corrosion Science 33 (1992) pp. 1677-1690. doi: 10.1016/0010938x(92)90002-k.

[32] W. Weisweiler and S. J. Ahmed, Kinetik der Festkörperreaktionen im System $\mathrm{CaO}-\mathrm{Al}_{2} \mathrm{O}_{3}$, Zement-Kalk-Gips 33 (1980) pp. 84-89. 
[33] M. A. Gülgün, O. O. Popoola and W. M. Kriven, Chemical synthesis and characterization of calcium aluminate powders, Journal of the American Ceramic Society 77 (1994) pp. 531-539. doi: 10.1111/j.1151-2916.1994.tb07026.x.

[34] B. M. Mohamed and J. H. Sharp, Kinetics and mechanism of formation of monocalcium aluminate, $\mathrm{CaAl}_{2} 2 \mathrm{O}_{4}$, Journal of Materials Chemistry 7 (1997) pp. 1595-1599. doi: 10.1039/A700201G.

[35] C. Ghoroi and A. K. Suresh, Solid-solid reaction kinetics: Formation of tricalcium aluminate, AIChE Journal 53 (2007) pp. 502-513. doi: 10.1002/aic.11086.

[36] C. Wagner, The evaluation of data obtained with diffusion couples of binary single-phase and multiphase systems, Acta Metallurgica 17 (1969) pp. 99-107. doi: 10.1016/0001-6160(69)90131-X.

[37] G. J. Yurek, J. P. Hirth and R. A. Rapp, The formation of two-phase layered scales on pure metals, Oxidation of Metals 8 (1974) pp. 265-281. doi: 10.1007/BF00609944.

[38] F. Gesmundo and F. Viani, The formation of multilayer scales in the parabolic oxidation of pure metals - I. relationships between the different rate constants, Corrosion Science 18 (1978) pp. 217-230. doi: 10.1016/S0010-938X(78)80019-5.

[39] F. Viani and F. Gesmundo, The relationships between the different rate constants and the diffusion properties of the oxides in the parabolic oxidation of a metal or a lower oxide to multilayer scales: application to the oxidation of iron, Corrosion Science 20 (1980) pp. 541-554. doi: 10.1016/0010-938X(80)90070-0.

[40] H. S. Hsu, The formation of multilayer scales on pure metals, Oxidation of Metals 26 (1986) pp. 315-332. doi: 10.1007/BF00659339.

[41] G. Wang, B. Gleeson and D. L. Douglass, Phenomenological treatment of multilayer growth, Oxidation of Metals 31 (1989) pp. 415-429. doi: 10.1007/BF00666465.

[42] A. H. Heuer, D. B. Hovis, J. L. Smialek and B. Gleeson, Alumina scale formation: A new perspective, Journal of the American Ceramic Society 94 (2011) pp. s146-s153. doi: 10.1111/j.1551-2916.2011.04573.x.

[43] J. Doychak, J. L. Smialek and T. E. Mitchell, Transient oxidation of singlecrystal $\beta$-NiAl, Metallurgical Transactions A 20 (1989) pp. 499-518. doi: 10.1007/BF02653930.

[44] J. Jedlinski and G. Borchardt, On the oxidation mechanism of alumina formers, Oxidation of Metals 36 (1991) pp. 317-337. doi: 10.1007/BF00662968.

[45] B. Pint, J. Martin and L. Hobbs, The oxidation mechanism of $\theta-\mathrm{Al}_{2} \mathrm{O}_{3}$ scales, Solid State Ionics 78 (1995) pp. 99-107. doi: 10.1016/0167-2738(95)00013-V.

[46] C. Wagner, Theoretical analysis of the diffusion processes determining the oxidation rate of alloys, Journal of the Electrochemical Society 99 (1952) pp. 369 380. doi: 10.1149/1.2779605.

[47] J. A. Nesbitt and R. W. Heckel, Interdiffusion in Ni-rich, Ni-Cr-Al alloys at $1100{ }^{\circ} \mathrm{C}$ and $1200{ }^{\circ} \mathrm{C}$. II. Diffusion-coefficients and predicted concentration profiles, Metallurgical Transactions A-Physical Metallurgy and Materials Science 18 (1987) pp. 2075-2086. doi: 10.1007/bf02647079. 
[48] C. E. Campbell, W. J. Boettinger and U. R. Kattner, Development of a diffusion mobility database for Ni-base superalloys, Acta Materialia 50 (2002) pp. 775792. doi: 10.1016/s1359-6454(01)00383-4.

[49] A. Andoh, S. Taniguchi and T. Shibata, TEM observation of phase transformations of alumina scales formed on Al-deposited Fe-Cr-Al foils, Materials Science Forum 369-372 (2001) pp. 303-310. doi: 10.4028/www.scientific.net/MSF.369372.303.

[50] Z. Li, Investigation of the Minor-Element Effects on the Oxidation Behavior of $\gamma-\mathrm{Ni}+\gamma^{\prime}-\mathrm{Ni}_{3} \mathrm{Al}$ Alloys. PhD thesis University of Pittsburgh (2015). http: //d-scholarship.pitt.edu/23418/.

[51] F. Gesmundo and B. Gleeson, Oxidation of multicomponent two-phase alloys, Oxidation of Metals 44 (1995) pp. 211-237. doi: 10.1007/BF01046728.

[52] P. Carter, B. Gleeson and D. Young, Calculation of precipitate dissolution zone kinetics in oxidising binary two-phase alloys, Acta Materialia 44 (1996) pp. 4033-4038. doi: 10.1016/S1359-6454(96)00054-7.

[53] T. J. Nijdam and W. G. Sloof, Modelling of composition and phase changes in multiphase alloys due to growth of an oxide layer, Acta Materialia 56 (2008) pp. 4972-4983. doi: 10.1016/j.actamat.2008.06.010. 